\title{
XI. YÜZYILDA ANADOLU'DA MEYDANA GELEN DOĞAL AFETLER
}

\section{Ömer SUBAŞI*}

\author{
Öz
}

XI. yüzyılda Anadolu'da çeşitli doğal afet ve felaketler yaşanmıştır. Meydana gelen bu olayların birçoğu dönem içerisinde kaleme alınan tarihî kaynaklarda kendilerine yer bulmuştur. Kaynak yazarları kaleme aldıkları eserlerde çoğunlukla siyasi hadiselere yer verirken yüzyıl boyunca yaşanan depremlerden; yıldız kaymaları ve kuyruklu yıldız gibi gökyüzü olaylarından; kıtlık, kuraklık ve salgın hastalıklar ile büyük tahribata neden olan atmosfer olaylarından da bahsetmişlerdir. Bu çalışmada XI. yüzyıl Anadolu'sunda birçok insanın ölümüne neden olan doğal afet ve felaketler ile bu vakaların toplum üzerindeki etkileri ele alınmıştır.

Anahtar Sözcükler: Doğal afetler, depremler, kıtlık, açlık, salgın hastalıklar, gökyüzü olayları.

\section{NATURAL DISASTERS WHICH TOOK PLACE IN ANATOLIA IN THE $11^{\text {th }}$ CENTURY}

\begin{abstract}
There were various natural disasters occurred in the 11th century Anatolia. Most of these natural events are present in the historical sources which were written in the same period. The writers included mostly political events in their work; however, they also gave place to earthquakes, events in the sky like; falling stars and comets, famine, drought and epidemic illnesses together with atmospheric phenomenon that caused great destructions. This study deals with natural disasters and disasters in the 11th century that caused many people's death in Anatolia and the effect of these incidents on the society.
\end{abstract}

Keywords: Natural Disasters, Earthquakes, Famine, Drought, Epidemics, Events in the Sky.

\section{Giriş}

Dünya üzerindeki bütün toplumlar farklı zaman dilimlerinde çok çeşitli doğa olaylarına veya felaketlere maruz kalmışlardır. Bu hadiseler içerisinde yıkıcı etkisi en fazla olan deprem, uzun yıllar insanoğlunun sebebini anlamak için yoğun çaba sarf ettiği önemli bir tabiat olayıdır. Hristiyan yazarlar, eserlerinde halkların günlük yaşamlarını bu denli derinden etkileyen depremlerden sıklıkla bahseder ve genellikle kendileri için kutsal saydıkları, insan eliyle yapılan binaların, sarayların, surların, kilise veya havra gibi ibadethanelerin yıkılmasından veya yok olmasından bahsederken o sırada bu yıkıntılar altında kalarak can veren insan sayısını fazlaca dikkate almazlar. Ancak yazarlar, deprem esnasında hayatını kaybeden toplum için önemli

\footnotetext{
*Yrd. Doç. Dr.; Artvin Çoruh Üniversitesi Fen Edebiyat Fakültesi Tarih Bölümü, Subasi.omer25@ gmail.com.
} 
şahısların isimlerine kayıtlarında özellikle yer vermektedirler. Hristiyan yazarlara ek olarak Müslüman yazarlar da eserlerinde kısaca can kaybına ve maddi hasara değinirler ve özellikle de yeryüzünde meydana gelen jeolojik ve fiziksel durumlar ile değişikliklere oldukça yer verirler. Kaynaklarda depremlerin şiddeti yani depremin yeryüzündeki etkileri hakkında bilgiler mevcut iken, büyüklüğünü nicel olarak ölçecek aletler kullanılamadan önce şiddetlerine göre sınıflandırılmakta; insanların olay anındaki kişisel tepkileri ile gözlemlenen ya da kaydedilen fiziksel hasarlar göz önüne alınmaktayd1. ${ }^{1}$ Kronolojik bir şekilde kaleme alınan tarihî kaynaklar, dönem içerisinde yaşanan olayları yıllar başlığı altında verdiğinden o yıl içerisinde yaşanan sadece siyasi olayları değil toplumu etkileyen ve insanların hafızasında yer etmiş neredeyse bütün doğa olaylarından da bahsetmektedirler. XI. yüzyılda yaşananlara dair bilgiler barındıran gerek İslam gerekse Hristiyan kaynaklarda insanoğlunun maruz kaldığ depremin yaratmış olduğu zarara eşdeğer bir zayiata neden olan salgın hastalıklar, kıtlık ve kuraklık gibi afetlere de rastlamaktayız. Kaynaklar bu hadiseleri de diğer vakalar gibi kronolojik sıra ile vermiş olsa da yazarların kaleme alış tarzından anlaşıldığı kadarıyla yaşananları birbirlerinden ayrı düşünmek çok da mümkün değildir. Ancak diğer birçok olayda olduğu gibi bu tür olaylar içinde sebep arama çabası içerisinde olan Hristiyan yazarlardaki genel kanı, yaşananlar tanrının onları cezalandırmaya yönelik bir faaliyetidir. XI. yüzyıl süresince meydana gelen ve birçok insanın ölümüne neden olan bu tür hadiseler, Müslüman yazarların bu dönemi kapsayan kayıtlarında Anadolu Coğrafyası için yok denecek kadar da azdır.

Bu felaketlere ek olarak kaynaklarda sıkça karşılaşılan bir başka sıra dışı doğa olayı ise gökyüzü ve atmosfer olaylarıdır. Hristiyan yazarlar genel olarak bu olaylara dair fikirlerini beyan ederken olayı geleceğe yönelik kehanet veya bir felaketin nişanesi olarak görmüşlerdir. İslami yazarlar ise olayları kayıtlarında yıl içerisinde yaşananlar başlığı altında vermiş ve hadiseleri sadece sıradan bir gökyüzü veya atmosfer olayları olarak ifade etmişlerdir.

XI. yüzyılda yaşanan doğa olayları hakkında bilgi almak için başvurduğumuz Müslüman yazarların başında gelen İbnü'l-Esîr, eserindeki üslubun kuruluğuna rağmen konunun uygun düştüğü yerlerde olayı dramatikleştirme gücünü de göstermiştir. İbn Kesîr'in tarihinde ise olaylara dair diğer eserlere oranla daha ince bir eleştiri düşüncesi egemendir. ${ }^{2}$ Müslüman yazarların olayları ifade ediş tarzıyla farklılık gösteren Hristiyan yazarların başında Urfalı Mateos gelir. Yazar, dil ve üslup bakımından edebî metinlerden uzak, kitabını kendi

${ }^{1}$ Nuh Arslantaş, İslam Dünyasında Depremler ve Algılanma Biçimler, İstanbul 2003, s. 21-23.

2 M. Şemseddin Günaltay, İslam Tarihinin Kaynaklart-Tarih ve Müverrihler, Endülüs Yay., İstanbul 1991, s. 155, 328. 
zamanının halk dili ile karışık basit bir lisan ve edebî zarafetten mahrum bir üslup kullanarak yazmıştır. En tesirli vakaları bile hiç heyecana kapılmadan adi vakalar gibi kaydeder. Mateos, edebiyat yapmaktan ziyade vakaları objektif bir surette sadıkane kaydetmeyi tasarlamış ve bundan dolayı bir tarih kaynağı olarak dolgun ve nispeten mevsuk bir eser bırakmıştır. ${ }^{3}$ Benzer ifadelere rastladığımız Simbat Vekayinamesi ise Urfalı Mateos ve Papaz Grigor'un yazılarının bazı ufak farklarla meydana getirilmiş basit bir hülasasıdır. ${ }^{4}$ Yaşanan olaylara dair önemli bilgiler barındıran XI ve XII. yüzyı1 Bizans tarihçilerinden Skylitzes, Attaleiates ve Zonaras, ${ }^{5}$ olaylar sonrası meydana gelen zararları diğer Hristiyan yazarlar gibi bazen bina veya kilise gibi yapılar üzerinden vermişler bazen de sadece olayın olduğunu fakat nerede yaşandığına dair hiçbir bilgi paylaşmamışlardır.

\section{A) Tarihî Kaynak Yazarlarının Yaşanan Doğa Olaylarına Dair Düşünceleri}

Tarih öncesi dönemlerden beri sıra dışı doğa olayları devamlı olarak tarihî kayıtlarda kendilerine yer bulmuştur. Gerek sözlü gerekse yazılı kaynaklarda kendilerinden çokça bahsedilen olayların oluş nedenleri için çeşitli fikirler öne sürülmüş özellikle Hristiyan nüfusun yoğun olarak bulunduğu coğrafyalarda yaşayan toplumlar tarafindan bu olaylar farklı yorumlanmıştır. Anadolu Coğrafyası' nda XI. yüzyılda çok farklı doğa olayları meydana gelmiş bu olaylar ve sonuçları tarihî kaynaklar vasıtasıyla günümüze kadar ulaşmıştır. Bu dönemde Anadolu'da yaşanan doğa olayları içerisinde yıkıcı etkisi en büyük olan depremlere sebep arama çabası içerisindeki yazarlar, bu amaç doğrultusunda yoğun olarak çalışmışlardır. Bizanslı tarihçi Attaleiates; deprem sarsıntıları, dünyanın boşluğundaki suların hareketlenmesinden ve bu boşluktaki rüzgârların döngeçler oluşturmasından ileri gelir iddiasını kabul etmez. Ona göre depremler eğer dünyanın boşlukları içerisindeki rüzgâr ve su hareketlerinden meydana gelmiş olsaydı sarsıntılar belirli aralıklarla gerçekleşip duruyor olmazdı. Tersine, düzenli ve güçlü sarsıntılar kanıtlıyordu ki deprem, Tanrısal bir işarettir; bizim ihtiraslarımızı zapt etmemiz ve aklımızı başımıza devşirmemiz içindir. $\mathrm{Bu}$ çıkışma, insan soyunun yok olmasını değil düzelmesini amaçlayan sabırlı Tanrı'nın işi idi. Deprem, Tanrı'nın isteğiyle ortaya çıkar; çünkü Tanrı, insanların işlerine doğrudan doğruya karışarak yönlendirmede bulunmaz. Böylece yağmur bulutlarının toplanmasına yahut gök gürlemesine veya şimşek çakmasına bunların

\footnotetext{
${ }^{3}$ Hrand D. Andreasyan, “Türk Tarihine Aid Ermeni Kaynakları", İstanbul Ünv. Edebiyat Fakültesi Tarih Dergisi, C 1, Say1 1., İstanbul 1949, s. 104.

${ }^{4}$ Hrand D. Andreasyan, “Türk Tarihine Aid Ermeni Kaynakları”, İstanbul Ünv. Edebiyat Fakültesi Tarih Dergisi, C 1, Sayı 2., İstanbul 1950, s. 411.

${ }^{5}$ Melek Delilbaşı, “'Türk Tarihinin Bizans Kaynakları’, Cogito- Bizans-, Say1 17, Yapı Kredi Yay., İstanbul 1999, s. 341.
} 
çarpışması neden olmuş gibi görünmesi mümkündür; ama bütün bunlar, dindar kişilere göre Tanrı'nın takdirine bağlı olmaktan geri durmazlar. ${ }^{6}$

Depremlerin oluş nedenleri üzerine diğer Bizanslı tarihçi Mikhail Psellos'in 23 Ekim 1063 depreminden sonra halkı teskin etmek için yapmış olduğu heyecanlı bir konuşması mevcuttur. $\mathrm{Bu}$ tarihçi, depremin nedenini açıklayarak halkın korkusunu yatıştırabileceğini sanıyordu: "Doğa, olağan düzenini kaybetti çünkü Tanrı öfkesini dolaylı yolla, doğadaki kaosla göstermek istedi." Psellos'a göre bütün dünya bir kitaptır. Orada Tanrı'nın istediği okunabilir ve vaiz onun içindeki işaretleri yorumlamalıdır. Doğa, Tanrı tarafından insan onun yasalarına uyduğu sürece ahenkli bir şekilde düzenlenmiştir. Fakat günahlar işlendiği zaman, karışıklık doğaya egemen olmaktadır. İnsan, inananı doğru yolda tutmak için Tanrı'nın bir uyarısı olan depremin nedenidir. Psellos, bununla birlikte depremleri yerin içindeki rüzgâr hareketleri ile açıklayan Aristo'nun teorisini de bilmektedir. ${ }^{7}$ Buna rağmen o, yine rüzgârın yeri sarsması için emri verenin Tanrı olduğunu ileri sürmektedir. ${ }^{8}$

Ancak dönem içerisinde Anadolu'da baskın güç olarak bilinen Rumlar, uğradıkları tabii felaketleri, dinden sapmalar dolayısıyla Tanrı'nın kendilerine verdiği ceza olarak görüyorlardı. Yaşanan doğal olaylar, düşman saldırılarının büyük artışı ve Rum devleti uyruklularının kıyımdan geçirilmesi, Tanrı'nın, İberia ve Mezopotamya'da yaşayan ve Lykandos'a, Melitene'ye ve onun çevresindeki yörelere kadar yayılan din sapmalarına karşı öfkesinin bir sonucu sayılmıştır. ${ }^{9}$ Ancak Bizanslı tarihçilerin aksine Ermeni yazarlar, olayların sorumlusu

\footnotetext{
${ }^{6}$ Michaelis Attaliotae, Historia, (Invent, Descript, Correct Immanel Bekkerus), Bonnae 1853, s. 88,89; Mikhael Attaleiates, Tarih, çev.: Bilge Umar, Arkeoloji ve Sanat Yay., İstanbul 2008, s. 96, 97.

${ }^{7}$ Depremleri izah etmeye çalışan en önemli filozoflardan birisi olan Aristo'ya göre temel kavram, rüzgar ve buhardır. Ona göre yeryüzü tabiatı icabı kurudur; fakat yağmur yağdığı zaman onu 1slatır. Güneş 1şınları yağan yağmurlarla iyice ıslanarak nemlenen toprağa vurduğu zaman çıkardığı yanıcı ve kuru buhar, rüzgarın da etkisiyle toprağın damarlarında yeri yırtarcasına hızla yol alarak, tabiatın kendisine ayırdığı yerini ararken depreme sebep olur. Aristo, Meteorologica,-The Works of Aristotle-, Vol III., By, E.W. Webster.-Trans.: W.D.Ross, M.A., Hom LL.D., Oxford 1931, s. 365b-366a; Arslantaş, İslam Dünyasında Depremler ve Algılanma Biçimler, s. 38, 39.

${ }^{8}$ Frank Vercleyen, "Bizans Döneminde İstanbul'da Depremler: Halk Üzerinde Etki”, Ankara Üniversitesi Dil ve Tarih-Coğrafya Fakültesi Tarih Bölümü Tarih Araştırmaları Dergisi, Fransızcadan çev.: Feda Şamil Arık, Cilt. 19, Sayı 30, Ankara 1997, s. 310; Paul Gautier, "Monodie inédite de Michel Psellos sur le basileus Andrınic Doucas", Revue des études byzantnes tome 24, 1966, s. 153-170; Eserinde kendine dair bilgiler vermekten çekinmeyen Psellos, bir ara Horoskopia ile ilgilendiğini ve yıldızların duruşlarının veya görünüşlerinin dünyada yaşanan olaylara hiçbir tesirinin olmadığını açıkça ifade etmiştir. Mikhail Psellos Khronographia'sl, çev.: Iş̧ı Demirkent, TTK. Yay., Ankara 1992, s. 164.

${ }^{9} \mathrm{Bu}$ bölgelere yayıldıkları söylenen topluluk Ermenilerdir ve yukarıda adı geçen bölgelerde kalabalık bir Ermeni nüfusu mevcuttur. Ancak yazara göre kötü yazgı Ortodokslara da yayılmaya başlayınca Rumlarla aynı dinsel inançta olanların Gürcüler gibi toplumlarda felaketlerden kendilerine düşen payı aldılar. Bizanslılara göre Ermeniler, Hz. İsa'nın tanrı mı insan mı olduğu gibi konularda İznik piskoposları kurultayının hem Ortodoks hem Katolik kilisesince benimsenmiş yorum ve kararlarını kabul etmeyen bir kilise örgütüne bağl "Gregoryen" denen mezhebe mensupturlar ve Bizanslılar, Ortodoks mezhebinde olmalarından dolayı genellikle Gregoryen mezhebine mensup Ermenileri dinsiz olarak görürlerdi. Anna Komnena, Alexiad, Anadolu'da ve Balkan Yarımadası'nda İmparator Alexios Komnenos
} 
olarak Rumları görmüşler ve başlarına gelen bütün felaketlerin, günahlarının cezası olarak meydana geldiğine inanmışlardır. Devamında ise felaketlerin nedenlerini arayan kaynak yazarları tarafından Tanrı'nın kendilerini cezalandırmak amacıyla göndermiş olduğu Türklerin, kısa zamanda İstanbul'a ve Anadolu'nun dört bir yanına ulaşmasının müsebbibi olarak Ermenileri yerlerinden ederek krallarını deviren Bizanslılar gösterilmiştir. ${ }^{10}$

Karş1lıklı suçlamalarla devam eden kayıtlar içerisinde özellikle Ermeni yazarlar, bölgede meydana gelen doğa olayları ile Türk akınları arasında bağlantı kurabilmek için yoğun bir çaba sarf etmişlerdir. Hatta bu yüzyılın ilk çeyreğinde yaşanan iki gökyüzü olayını yorumlayan Ermeni Rahip Hovannes Gozern, son zamanlarda işlenen fenalıklardan dolayı memlekette büyük felaketlerin olacağı kehanetinde bulunmuş ve ilerleyen dönemlerde Hristiyan toplum ve ruhani sınıf içerisinde bozulmaların olacağını söylemiş ve kehanetlerine: "Bu zamanda Müslümanların taarruzları vuku bulacak. Ham'ın oğulları olan Türk askerleri, Hristiyan milletlerin üzerine gelecekler; bütün memleketi k1lıçla tahrip edecekler ve bütün Hristiyanlar, açlık ve esaret yüzünden mahvolacaklardır." diye devam etmiştir. ${ }^{11}$ Anadolu'ya yapılan Türk akınlarını tarif eden Mateos ise Hristiyanlar üzerine yıkıcı bir hava ile acı darbeler vurulduğunu söyler ve bütün Hristiyanların matem ve yeis içinde kaldıklarını iddia ederek Allah'ın onlardan yüz çevirdiğini düşünür. Yazar, Allah'ın onları, günahlarından ve fena yollara sapmalarından dolayı zalim Türklerin eline bıraktığına inanmıştır. 1062 / 63 tarihinde yapılan Türk akınlarını tarif eden Mateos, Hristiyanlar üzerine yıkıcı bir hava ile acı darbeler vurulduğunu söyleyerek konuyu anlatmaya başlamış ve bütün Hristiyanların matem ve yeis içinde kaldıklarını; çünkü Allah'ın onlardan yüz çevirdiğini düşünmüştür. Sözlerine devam eden yazar, Allah'ın onları günahlarından ve fena yollara sapmalarından dolayı zalim Türklerin eline bıraktığına inanmıştır. Yaşanan bu felaketlerin nişanesi, horozların akşamleyin ötmesi veya

Dönemi'nin Tarihi, Malazgirt'in Sonrası, çev.: Bilge Umar, İstanbul 1996, s. 287; Attaleiates, Tarih, s, 104; Michaelis Attaliotae, Historia, s. 96, 97.

${ }^{10}$ Öyle ki Urfalı Mateos, Türklerin, Bizanslıları, İstanbul'a hapsettikten sonra Ermenistan'1 Bizanslıların elinden kurtardığını söyler ve Türklerle savaşmaktan korkan Rumların bundan sonra Ermeni mezhebini tetkik ederek kilise içerisinde kargaşa çıkarmak için çalıştıklarını ve Ermenileri dinlerinden döndürmeye uğraştıklarını iddia etmiştir; Urfalı Mateos Vekayi-Nâmesi (952-1336) ve Papaz Girgor'un Zeyli (1136-162), çev.: Hrand D. Andreasyan, Not. Edouard Dulaurer, M. Halil Yınanç, TTK. Yay., Ankara 2000, s. 111, 112; Başkumandan Simbat Vekayinamesi (9511334), Türkçeye çev.: Hrant D. Andreasyan, TTK Basılmamış Nüsha, İstanbul 1946, s. 38, 39; Hrand D. Andreasyan, "Türk Tarihine Aid Ermeni Kaynakları", C.1, Sayı 1., s. 105.

${ }^{11}$ Hristiyanların Türklere dair kehanette bulunma çabaları ilk Türk akınları sonrası Senekerim'in yemeden içmeden derin düşüncelere daldıktan sonra geceleri sabahlara kadar uyumadan ve durmaksızın nebilerin yazı ve sözlerini tetkik ettikten sonra bu yazılarda Türk askerlerinin ilerleyeceği devri gördüğü ve yeryüzünün tahrip edilip sonra ereceği kehanetinde bulunmasıdır. Urfalı Mateos Vekayi-Nâmesi, s. 49,50-59-64; Başkumandan Simbat Vekayinamesi, s. 23. 
öküzlerin ve koyunların oturmuş vaziyette gübrelemesi olarak görülmüştür. ${ }^{12}$ Meydana gelen vakalardan Türkleri sorumlu tutan Ermeni yazarlar, 1079 - 80 yıllarında Anadolu'da yaşanan kıtlık olaylarını anlatırken Şark ve Grek memleketlerinin mahvolmasına neden olan olayların sebebini yine Türk akınları olarak görmüş ve bu yaşananları adil ve hâkim olan Tanrı'nın işledikleri günahlarından dolayı onlara verdiği bir ceza olarak düşünmüştür. Ancak yüzyılın sonlarına doğru meydana gelen haçlı seferlerinin başlangıcı sırasında yazar bir anda fikrini değiş̧irir ve Tanrı'nın önceleri kendilerini cezalandırmak için gönderdiği Türklere karşı Latinlerin vasıtasıyla harp etmek istediğini iddia eder. ${ }^{13}$

Hristiyan yazarların olayları tarif ve tanımlamak için kullandıkları ifadelerin benzerlerine uzak coğrafyalarda kaleme alınmış Gürcü kroniklerinde de rastlamak mümkündür. Kronikte, 1088 y1lında memlekette meydana gelen olaylara bir sebep olarak Kakheti Kralı'nın Müslüman olması ile her yaştan her vaziyetteki insanın doğru yolu terk ederek her türlü fenalığı işlediği ve Allah'1 gücendirdiklerini söyler. Yaşanan o kadar çok afetin bile Allah'ın onlara karşı duyduğu hiddete bir son vermediğini, ayrıca yaşanan olaylardan hiçbir ders çıkarmadıklarını belirtir. Hatta kaynak, bazılarının "Olan olayların sebebi, günahlarının bir karşılığı olarak Allah tarafından verilen bir ceza olmadığını, ancak devri ihtilaller ve dünyanın tesadüfi karışıklıklarıdır.” demelerini kabul etmeyerek kendi fikrini desteklemek amacıyla başka örnekler sunar ve memlekette yaşanan felaketlerden başka gökten başlarına diğer korkunç alametler ve başka cezalar dahi gönderildiğini iddia edip Allah'ın dünyaya hiddetli bir bakış gösterdiğini söyler. ${ }^{14}$ Yaşanan doğa olaylarına aynı pencereden bakmaya devam eden Bizanslı yazar Attaleiates, yaşanan olayları ileriye dönük kehanetler olarak da görmektedir. Ona göre uğranılan bahtsızlıklar gerçekten insanların günahlarından dolayı verilmiş cezalarıdır. Yazara göre: "1063-65 yılında yaşanan deprem olaylarının olacağı vardı da ondan olmuştur ve Tanrı'nın gazaba gelmesi yüzünden günahlarımızın cezalandırllması için oldu. Ne var ki bunlar aynı zamanda düşmanlarının kısa zaman içinde saldırıya geçeceğini ve işin sonunda mahvolacaklarının bir alameti idi. "15 Düşüncelerine somut örnekler vererek devam eden yazar, 1076 - 77 yılında İstanbul'da gelecekte olacaklar için emare niteliğinde bazı olaylar gerçekleştiğini iddia etmiştir. O dönemde başkentte üçayaklı bir civciv ile yüzünde sadece tek gözü bulunan ve keçininki gibi ayakları olan bir bebeğin doğması hatta onun doğal bir

\footnotetext{
${ }^{12}$ Urfall Mateos Vekayi-Nâmesi, s. 115.

${ }^{13}$ Urfalı Mateos Vekayi-Nâmesi, s. 115-156-187; Başkumandan Simbat Vekayinamesi, s. 45.

${ }^{14}$ Marie F. Brosset, Gürcistan Tarihi, (Eski Çağlardan 1212 yılına Kadar), (çev.: Hrand D. Andreasyan), Not. ve Yay., Erdoğan Merçil, TTK. Yay., Ankara 2003, s. 309.

${ }^{15}$ Michaelis Attaliotae, Historia, s. 90, 91; Attaleiates, Tarih, s. 98.
} 
çocuğunkine benzeyen sesle ağlarken Diakonissa semtinde sokağa bırakılması yazara göre, Tanrı'nın gösterdiği işaretlerdir ve bunlar sayesinde gelecekte olacaklar hakkında bir takım hükümlere varmak mümkündür. ${ }^{16}$

Başka bir Bizans tarihçisi Skylitzes de doğa olaylarını yorumlarken meydana gelen vakaları ileriye dönük kehanetler olarak düşünmüştür. Yazar, Thrakesion themasında meydana gelen bir olayı felaket nişanesi olarak görmüş ve şu şekilde kaleme almıştır: "Mükemmel ve berrak bir suyun bulunduğu yüksek Kouzenas Dă̆g'nda şaşırtıcı bir mucize oldu. İnleyen, ağlayan ve feryat eden kederli bir kadın sesine benzer bir ses duyuldu. Bu, sadece bir iki değil her gün ve her gece marttan hazirana kadar devam etti. Bazı insanlar duyulan bu sesi araştırmak için bu yere geldiklerinde gelecekte Suriye'de meydana gelecek olan bir Roma felaketinin nişanesi olarak bu sesi gördüler." ${ }^{17}$ XI. yüzyılın sonlarına doğru kaleme alınan Alexiad isimli eserin yazarı Anna Komnena, doğa olaylarını meydana gelecek herhangi bir felaketin nişanesi olarak gören diğer Bizanslı tarihçiler ile benzer ifadeler kullanmıştır. Bizanslı tarihçi, I. Haçlı Seferi öncesinde büyük halk kitlelerinin gelişinden önce ekinleri yemeyen ama bağları kemirerek yok eden bir çekirge salgınının meydana geldiğini söylemektedir. Yazara göre bu olay zamanın falcıları tarafından şöyle izah edilmektedir: "Kelt Ordusu hedefine vardığı zaman Hristiyanların işlerine bir zarar vermeyecek; ama sarhoşluğun, şarabın ve şarap tanrısı Dionysos'un köleleri olan Barbar İsmailoğullarını (Türkleri) korkunç biçimde ezeceklerdir.” Diyerek yaşananları bir belirti olarak gördüklerini iddia etmektedir. ${ }^{18}$ Özellikle Ermeni ve Bizanslı tarihçilerin eserlerinden aktarılan örneklerden de anlaşıldığı gibi yazarlar bazen afetlerin sorumlusu olarak birbirlerini suçlamışlar bazen de kendilerinin dinden sapmalarını sorumlu tutmuşlardır. Ancak Türklerin, Anadolu içlerine doğru ilerledikleri zamanlarda bu düşünceleri değişmeye başlamış ve Hristiyan yazarlar kısmen Türkleri, kendilerine Tanrı tarafından gönderilen bir ceza olarak görmüş kısmen de Türklerin yaptıkları akınları birer yağma ve istila olarak algıladıkları için kıtlığın, sefaletin ve yoksulluğun hatta salgın hastalıkların sorumlusu olarak bu akınları düşünmüşlerdir.

\section{B) XI. Yüzyılda Anadolu'da Meydana Gelen Depremler}

XI. yüzy1lda Anadolu'daki depremlerle ilgili en eski ve en önemli bilgilere bir Bizans kaynağında rastlamak mümkündür. Bizans tarihçisi Skylitzes’in yazdıklarına bakılırsa, 1010 /

\footnotetext{
${ }^{16}$ Michaelis Attaliotae, Historia, s. 211; Attaleiates, Tarih, s. 212.

17 John Skylitzes, A Synopsis of Byzantine History, 811-1057, Introduction, Text And Notes Translated By John Wortley, Cambridge University Press 2011, s. 357.

${ }^{18}$ Anna Komnena, Alexiad,, s. 304.
} 
1011 yılının Ocak ayında müthiş bir deprem oldu. Dünya, Mart ayının dokuzuna kadar sarsılmaya devam etti. Bu günün onuncu saatinde themalarda ve başkentte (İstanbul) korkunç bir sarsıntı ve titreme oldu; hatta bu sarsıntıda kiliselerin kubbeleri yıkıldı. ${ }^{19}$

1010 / 1011 yılındaki deprem bilgisinden sonra konuyla ilgili ikinci kayttlar yine aynı tarihçiye aittir. Skylitzes, 1030 ile 1040’l1 yıllar arasında Anadolu ve çevresinde meydana gelen yaklaşık altı büyük depremin olduğundan söz etmektedir. Tarihçinin kayıtlarından anlaşıldığ kadarıyla bu yıllardaki ilk deprem 13 Ağustos 1032 Pazar günü şiddetli bir sarsıntıyla gecenin ilk saatinde meydana geldi. İmparator, eşi Helena ile ölüm olaylarının yaşandığı başkente geldiler. Ardından o, yandaşlarına çokça sadaka dağıttı. 6 Mart günü üçüncü saatte bir deprem daha oldu ${ }^{20}$ Yine Bizanslı tarihçi Zonaras, depremi şöyle anlatır: "1032'de depremler oldu. Bunların sonrasında Byzantion'un karşısında bulunan birçok hanlar, keza hastaneler yıkıldı; o hastaneler eskiden beri saralılar ile cüzamlıların kalma yeriydi. Imparator, bu yapıları yeniletti ve İstanbul'a su getiren zarar görmüs boruların bakımını yaptırdı. "21

$\mathrm{Bu}$ dönemde yaşanan depremlerle alakalı bilgiler vermeye devam eden Skylitzes'e göre 1030'lu yıllardaki ikinci önemli deprem, Anadolu'dan farklı bir bölgede yaşanmış ve bu deprem 17 Şubat 1034 tarihinde olmuştur. Depremin yaşandığ Suriye şehirleri bu felaketten büyük zarar görmüştür. ${ }^{22}$ Ancak yazar, depremin hangi şehirleri etkilediğini açıkça belirtmemiştir. Tarihçi tarafindan anlatılan başka bir deprem ise 18 Aralık 1036 tarihinde gecenin dördüncü saatinde olmuş ve iki küçük ile bir büyük olmak üzere toplam üç deprem yaşanmıştır. Ancak yazar bu depremlerin de nerede yaşandığını ve meydana gelen zarar hakkında herhangi bir bilgi vermemiştir. Bu tarihler arasında yaşanan başka bir deprem ise 2 Kasım 1037 tarihinde günün onuncu saatinde meydana gelmiş ve dünya uzun süre sallanmaya devam etmiştir. Bu depremin artçıları ocak ayına kadar sürmüştür. Bu olaydan iki yıl sonra 1039 yılında yine depremler yaşanmış ve kaynaklara geçecek kadar önemli sonuçlara sebebiyet veren şiddetli yağmur olayları meydana gelmiş hatta themaların bazılarında büyük salgın hastalıkları da ortaya çıkmıştır. Yazar, özellikle Batı Anadolu'da etkili olan ve 1040 yılının 2 Şubatı'nda meydana gelen korkunç bir depremden de bahseder. Deprem, etkilediği bölgelerde bütün evleri ve şehirleri yıkmış; ayrıca İzmir'de (Smyrna) yıkılan güzel binaların yıkıntıları acıklı görüntülere

\footnotetext{
${ }^{19}$ Skylitzes, A Synopsis of Byzantine History, s. 330.

${ }^{20}$ Skylitzes, A Synopsis of Byzantine History, s. 364,365.

${ }^{21}$ Ioannis Zonarae, Epitomae Historiarum, Libri XIII-XVIII, Edit, Theodorus Büttner-Wobst, Bonnae Impensisi Ed. Weberi 1897, s. 580, 581; Ioannes Zonaras, Tarihlerin Özeti, çev.: Bilge Umar, Arkeoloji Sanat Yay., İstanbul 2008, s. 52, 53.

${ }^{22}$ Skylitzes, A Synopsis of Byzantine History, s. 367.
} 
sebebiyet vermiş; şehir sakinlerinin birçoğu bu depremde hayatlarını kaybetmiştir. ${ }^{23}$ Kayıttan anlaşıldığı kadarıyla yaşanan bu deprem, geniş bir alanı etkilemiş ve oluşturduğu sonuçlar itibariyle büyük bir coğrafyada zararlara sebebiyet vermiştir.

Azîmî, 1040 / 41'de Amid'de iki kez depremin olduğundan söz etmektedir. Fakat yazar, bu depremin yarattığı zarardan eserinde hiç bahsetmez. ${ }^{24}$ Skylitzes de aynı yıl içerisinde yaşanan bir depremden bahsetmektedir. Ona göre 10 Haziran 1041 tarihinde günün on ikinci saatinde bir deprem oldu. Ancak yazar bu depremin nerede olduğunu ve zararı hakkında herhangi bir bilgi vermemiştir. ${ }^{25}$

1044 / 45 tarihinde Tebriz'de tahribat yapan bir deprem yaşanmış ve bu deprem Amid ve Armeniye'ye dek uzanmıştır. Azîmî, yaşanan bu depremi oldukça sade bir dille kaleme alırken depremin yarattı̆ğ hasarı detaylı olarak veren İbnü'l-Esîr, Tebriz depreminin H. 434 (M. 1042,1043) y1lında meydana geldiğini söyler ve kısaca şöyle aktarır: “Tebriz'de büyük bir zelzele oldu. Şehrin kalesi, surları, evleri, pazar yerleri ve hükümet konağının büyük bir kısmı yıkıldl. Şehir halkından ölenlerin sayısı yaklaşık elli bin kadardı." ${ }^{26}$ Fasîh Hâfî, Tebriz'de yaşanan bu depremin tarihini H. 433 (1041,1042) olarak vermiştir. Müellif: “ Deprem sonrası harabeye dönen Tebriz ve çevresinde Halife Reşid'in zevcelerinden olan Zübeyde Hatun tarafindan yapılan imaretler de yıkılmıs ve bu yapılar Tebriz valisi tarafindan hızlı bir şekilde yeniden imar edilmiştir." demektedir. ${ }^{27}$ Urfalı Mateos ise her zamanki gibi yaşanan bu olayları Tanrı'nın insanlara verdiği bir ceza olarak görmüş ve deprem anında yaşananları oldukça canlı bir şekilde tasvir etmiştir. Ermeni yazara göre: “İnsanlar, Tanrı'nın şiddetli hiddetine maruz kaldılar. Tanrı, öfkeli bakışlarını mahlûklarına tevcih etti. Korkunç bir zelzele oldu ve Peygamberin “ o zemine nazar ettiğinde titrer” diye söylemiş olduğu veçhile bütün yeryüzü sarsıldı. Bütün arz ve mahlûklar bu suretle çalkalandı. Egeğiatz mıntıkasında birçok kilise temelinden yıkıldı ve Erzincan denilen şehir kâmilen harap oldu. Toprak yarıldı, erkekler ve kadınlar derinliklere yuvarlandılar ve bunların derinliklerden gelen acı feryatları günlerce

\footnotetext{
${ }^{23}$ Skylitzes, A Synopsis of Byzantine History, s. 377-379-381.

${ }^{24}$ Azîmî, Azîmî Tarihi, Selçuklular Dönemi ile ilgili Bölümler ( H.430-538=1038/39-1143/44), TTT. Yay., Ali Sevim, Ankara 2006, s. 4.

${ }^{25}$ Skylitzes, A Synopsis of Byzantine History, s. 389.

${ }^{26}$ Azîmî, Azîmî Tarihî, s. 8; İbnü'l-Esîr, El Kâmil Fi't-Tarih, çev.: Ahmet Ağırakça, Abdülkerim Özaydın, Yunus Apaydın, Zülfikar Tüccar, Beşir Eryarsoy, Bahar Yayınları, İstanbul 1985, C.IX., s. 391, 392; İbn Kesîr, halkın başlarına gelen bu musibetten ötürü bronz giydiklerini söylemektedir. İbn Kesîr, El Bidaye Ve'n Nihaye, çev.: Mehmet Keskin, Çağrı Yayınları, İstanbul 1985, C.XII., s. 141,142; Gregory Abû'l-Farac (Bar Habraeus), Abû'lFarac Tarihi, Süryaniceden İng. çev.: Ernast A. Wallis Budge, Trk. çev.: Ömer Rıza Doğrul, C.I., TTK. Yay., Ankara 1999, s. 298.

${ }^{27}$ Fasîh Ahmed b. Celaleddin Muhammed Hâfî, Mücmel-i Fasîhî, C. II., Neşr.: Muhammed Ferrruh, Meşhed 1340 (1961), s. 163.
} 
işitildi. Yaz mevsimi idi. Sarsintılar bütün sene devam etti. Yaz mevsiminde, yeryüzü karanlıkla örtülmüş̧ü. Güneş ve ay kana boyanmış gibi doğuyor; ancak gök ortalarına çıktıkları vakit berraklık kazanıyorlardl. Günahlarından dolayı Allah'ın hiddetine maruz kalan mahlûkatların akıbetini nakletmek mümkün değildir. ${ }^{\text {"28 }}$ Süryani Mikhail ise, Mateos'un anlattıklarının aksine 1045 yılında Erzincan'da sel felaketinin yaşandığını ve şehrin sular altında kaldığını söylemektedir. Mihail'e göre 1356 (1045) tarihinde Allah'ın müsaadesi ile Ermenistan'ın bir şehri olan Erzangai (Erzincan), sular altında kaldı. Orada, aslen Süryani ve Ortodoks olan Beni Cyriacus adlı dindar bir adam bulunuyordu. Bütün şehir sulara gömüldüğü esnada bu dindar adamın evi, bir gölle çevrilmiş olduğu hâlde bir şey olmadı ve aynen kaldı. Bu, fakirleri seven ve iyilik eden bir adam olduğu için Allah, diğerlerine bir ibret teşkil etmek üzere bu mucizeyi yapmıştır. Bu olaya dair bilgi sahibi olan Ermeni kaynaklar şehirde büyük bir deprem olduğunu ifade ederlerken; Süryani kaynaklar ise şehirde sel felaketinin yaşandığını; sadece aslen Süryani olan bir şahsın ve Süryani Cyriacus oğullarının manastırının bu felaketten zarar görmediğini iddia etmişlerdir. ${ }^{29}$

Ermeni tarihçiler yaşanan doğa olaylarını ileriye dönük kehanetler veya nişaneler olarak görme geleneklerine aralıksız olarak devam ederek her firsata buna dair düşüncelerini ifade etmişlerdir. Bu tarihçiler, 502 (8 Mart 1053 - 7 Mart 1054) tarihinde büyük Antakya Şehri’nde felaket alameti olan korkunç bir nişane belirdiğini söylerler. Onlara göre bu alamet, güneşin içinde göründü ve herkes hayret ve korku içine düştü. Bütün Hristiyanlar bundan dolayı dehşete kapıldılar; çünkü bu, Allah'ın muhakemesinin icra olunacağını ihtar ediyordu. Antakya'da yaşayan Romalılar ve Süryaniler arasındaki mezhepsel çatışmalar sırasında Romalılar, Süryani İncilini yakmalarından hemen sonra S. Bedros Kilisesi'ne girince binanın içinde korkunç bir gürültü kopmuş ve şiddetli bir deprem olduktan sonra bütün şehir sarsılmıştır. Başka bir günde de S.Bedros Kilisesi'nin üzerine gökten ateş düşmüş ve kilise temelden damına kadar bir fener gibi yanmıştır. Kilisenin bütün taşları yanmış ve minberin bulunduğu yerde toprak yarılmış ve sed derinliklere gömülmüştür. Bu kilise hariç Romalılara ait kırk kilise de aynı yangında yanarak yok olmuş; ancak Süryani ve Ermeni kiliselerine hiçbir zarar gelmemiştir. Bu olayların bir son bulmasını arzulayan Patrik, yanına toplanmış halk ile şehrin içerisini dolaşırken Horom Meydanı denilen yere geldikleri vakit öğleyin altıncı saatinde büyük bir zelzele olmuş ve patrik

${ }^{28}$ Urfalı Mateos Vekayi-Nâmesi, s. 81.

${ }^{29}$ Süryani Patrik Mihail Vakainamesi, İkinci Kısım (1042-1195), Türkçeye çev.: Hrant D. Andreasyan, T.T.K. Basılmamış Nüsha, İstanbul 1944, s. 18; Yunanlıların 1336 (M.1045) yılında Erzincan şehri sular altında kaldı ve yalnız ırken Süryani olan Cyriacus oğullarının manastırı kurtuldu. Fakat bu manastır da bir göl ile çevrilmiştir. Abû'lFarac, Abû'l-Farac Tarihi, s. 303; Başkumandan Simbat Vekayinamesi, s. 31. 
ile on bin kadar insan derinliklere gömülmüştür. Antakya halkı, türlü türlü günahlarından dolayı adil ve hâkim olan Allah'ın bu cezasına çarptırılmıştır. Mateos'a göre günahkâr Antakya Şehri'nde fenalık yapanlar gerek ateş gerekse toprağın yarılmasıyla telef edilmişlerdir. ${ }^{30}$

Bizans tarihçisi Attaleiates, 1063 yılında yaşanan ve özellikte Trakya Bölgesi’ni etkileyen deprem hakkında önemli bilgiler vermektedir. Ona göre: “O ylldan önce, yani ikinci “taşınmaz mallarda vergi değerini belirleme” döneminin Eylül ayında ayın 23 'ünde (23 Eylül 1063) birdenbire deprem oldu; bu daha öncekilerin hepsinden daha güçlü bir depremdi. Batı tarafindan başladı ve o kadar güçlüydü ki pek çok evi yıktı; evlerden ancak birazı zarar görmeden kurtuldu. Kiliseler dahi, onun şiddeti yüzünden belli noktalardan çatlaklar ve sütunları aletlerle kesilmiş gibi zarar gördü. Çünkü deprem onları yalnızca bir kez vurup ardından durmadl; tersine ardı ardına üç kez çok güçlü deprem sarsıntısı oldu. Halkta büyük korkuya sebep olan bu depremler o gece on ile on iki kadar oldu, ancak bunlar öncekiler kadar güçlü sarsıntılar değillerdi. Makedonya tarafinda kıyı kentlerinin çoğu, yani Tekirdăg (Raedestum-Rhaidestos), Panium (Barbaros) ve Mürefte (Myriophytum) yıkıma uğradılar. Orada hatta bazı daireler, keza birçok ev, temeline dek çöktü ve çok sayıda insan öldü. Hellespontos'da özellikle Kyzikos zarar gördü." ${ }^{31}$ Kaynağın vermiş olduğu detaylı bilgilerden, depremin Trakya Bölgesi’nde özellikle de Tekirdağ ve çevresinde büyük zarara sebebiyet verdiği ayrıca deprem sonrası uzun süre artçı sarsıntıların meydana geldiği anlaşılmaktadır.

Bizanslı tarihçiler Glycas ve Zonaras, 1063 yılı depreminden bahsederlerken sarsıntıların İznik’e kadar etki ettiğini ve şehirde yıkıntılara neden oluğunu söylerler. ${ }^{32}$ Ancak diğer bir Bizans tarihçisi Attaleiates, İznik’teki bu yıkımın iki yıl sonraki bir depremde meydana geldiğini iddia etmektedir. Ona göre: “1063 yllından sonraki iki yıl süreyle mevsimler boyunca

\footnotetext{
${ }^{30}$ Urfalı Mateos Vekayi-Nâmesi, s. 98, 99; Başkumandan Simbat Vekayinamesi, s. 34, 35; Müverrih Vardan bu olayın 1072 yılında yaşandığını ifade etmiş ve kısaca şöyle aktarmıştır: "1072 tarihinde Antakya'daki S.Bedros Kilisesi yakıldı. Büyük zelzele oldu ve Rum patriği bin kişi ile yarılmış toprak içine gömüldü, çünkü bunlar Ortodoks Asurilerinin incilini yakmışlardı. İncil, ateş içinden dört defa hiçbir şey olmaksızın tam olarak çıkmıştı. Ancak Rumların kudurmuş olduğu sırada İncil beşinci defa olarak ateşe atıldı ve Hz. İsa'nın Yahudilerden haçı kabul ettiği gibi bu defa İncil yandı.” Müverrih Vardan, Türk Fütuhatı Tarihi (889-1269), çev.: Hrant D. Andreasyan, İstanbul 1937, s. 178, 179.

${ }^{31}$ Michaelis Attaliotae, Historia, s. 88,89; Attaleiates, Tarih, s. 96,97; Michaelis Glycas, Annales, Immanuel Bekkerus, Bonnae 1836, s. 605, 606.

${ }^{32}$ Zonaras, bu depremden bahsederken güzel bir yapı olan Kyzikos'daki tapınağın da yıkıldığını; çok büyük ve ünlü bir yapı olan İznik'teki Kutsal Babalar Kilisesi'nin de (Ayia Sophia) sarsıntılardan zarar gördüğünü söylemektedir. Ioannis Zonarae, Epitomae Historiarum, s. 679,680; Zonaras, Tarihlerin Özeti, s, 119; Glycas, Annales, p. 606; Işın Demirkent ve Glanville Downey, meydana gelen bu depremin oluş yılı olarak 1064 yılının eylül ayı olarak belirtirler. Işın Demirkent, "Bizans Kaynaklarına Göre IV.-XI. Yüzyıllarda İstanbul'da ve Çevresinde Depremler", Tarih Boyunca Anadolu'da Doğal Afetler ve Deprem Semineri, 22-23 Mayıs 2000 İstanbul, s. 64; Glanville Downey, "Eartquakes at Constantinople an Vicinity", A.D. 342-1454, Speculum, Vol. 30, No. 4 (Oct., 1955), s. 600.
} 
zaman zaman depremler oldu ve insanlar büyük şaşkınlık yaşadl. Sürekli olarak iki yıl boyunca dünyanın sarsılması ilk kez görülmüş bir olaydı ve daha önce böylesi kaydedilmemişti. İki yıl geçtikten sonra (1064 veya 1065) güçlülük yönünden, artç küçük depremlerden daha büyük, ama başlangıçtakinden daha küçük bir deprem oldu ve Bithynia'daki Nikaia / İznik'e zarar verdi; kent neredeyse bütünüyle ylkıldı. Kentin en önemli ve en büyük kiliseleri, yani içinde Ayia Sophia kilisesi dahil sallandı ve yıkıldl; surlar, kentlilerin evleri gibi yerle bir oldu. Bütün bunların olacağı vardı da ondan oldu ve Tanrı'nın gazaba gelmesi yüzünden, günahlarımızın cezalandırılması için oldu. Ne var ki bunlar aynı zamanda hallerini tasvir ettiğimiz halkın saldırıya geçeceğinin ve işsin sonunda mahvolacă̆ının bir alameti idi. Çünkü Tanrı'nın gösterdiği işaretler sayesinde, yukarıda söylenenlerden başka gelecekte olacaklar hakkında da bir takım hükümlere varmamız mümkündür." 33

Azîmî 1074 / 1075 yılına ait kayıtlarında Antakya Şehri’nde meydana gelen bir depremden bahseder. O, bu dönemde Antakya kapısındaki Deyrülmülk’te taştan yapılmış bir su kurnasının içinde "bakır atlar üzerinde ok torbalarıyla bakırdan yapılmış yedi Türk'ü temsil eden" bir Türk tılsımının ortaya çıktığını ve bu tılsımlardan bir yıl sonra ise Türklerin, Antakya'y1 fethettiğini söylemiştir. Ancak gerek bir yıl sonra Antakya'nın Türkler tarafindan fethedileceğinin söylenmesi gerekse çıktığını iddia ettiği tılsım olayına benzer bir vakanın da 1091 - 92 Antakya depreminden sonra yıkılan bir sur altından çıkartılan heykel olayı ile benzerlik göstermesi Azîmî’nin bu olayları karıştırmış olma ihtimalini ortaya koymaktadır. ${ }^{34}$

Bizanslı tarihçilerden Glycas ve Zonaras, İmparator Aleksios Komnenos'un (10811118) ilk yılında (1081) yaşanan bir deprem hakkında bilgi vermekteler. Tarihçilerin anlattıklarından anlaşıldığı kadarıyla Ayios Nikolaos'un yarattığı mucizelerle ünlü kutlama gününde korkunç bir deprem olmuş; sonuçta birçok konut, kilise ve kentin kamusal dairelerini barındıran stoa yapıları harabeye dönmüş ve birçok insan yıkıntılar altında kalarak can vermiştir. ${ }^{35}$ Ancak Süryani Mikhail, İstanbul'da olan bu depremin tarihini 1085 olarak vermiş ve binlerce insanın telef olduğunu belirtmiştir. ${ }^{36}$

1080 / 81 yılında deniz (Akdeniz) sahilindeki yörelerde deprem olduğunu Azîmî’den öğrenmekteyiz. Ancak yazar, tam olarak depremin neleri etkilediğini açıç̧a ifade etmez. ${ }^{37}$

\footnotetext{
${ }^{33}$ Michaelis Attaliotae, Historia, s. 90,91; Attaleiates, Tarih, s. 98.

${ }^{34}$ Azîmî, Azîmî Tarihi, s. 24.

${ }^{35}$ Glycas, Annales, s. 620; Ioannis Zonarae, Epitomae Historiarum, s. 740; Zonaras, Tarihlerin Özeti, s. 167.

${ }^{36}$ Süryani Patrik Mihail Vakainamesi, s. 38.

${ }^{37}$ Azîmî, Azîmî Tarihi, s. 27.
} 
Süryani Mikhail ise yaşanan bu depremin 1082 yılında meydana geldiğini ve Antakya şehir surlarında 86 kulenin yıkıldığını söylemektedir. ${ }^{38}$ Şehir surları, Vali Yağıbasan'ın görevlendirdiği El-Kadı Hasan b. El-Mevc tarafından tamir edilmiştir. ${ }^{39}$

Anadolu'nun farklı yörelerinde yaşanan deprem olaylarının anlatıldığı kaynaklara ek olarak Gürcü kronikleri de benzer vakalardan bahseder. Gürcü kroniğinden anlaşıldığ kadarıyla 1088 y1lında İberia'da Samtskhe ve Javakheti Bölgesi'ni içine alan büyük bir deprem meydana gelmiş ve deprem sırasında Tmogvi Şehri bile yıkılmıştır. Deprem, kaynakta şöyle geçer: "Allah dünyaya hiddetli bir bakış gösterdi. Yeryüzü temelinden o kadar şiddetli sarsıldı ki en yüksek dağlar, en metin kayalar toz gibi süpürüldü; köy ve kasabalar alt üst oldu; kiliseler devrildi; ylkılan ve ezilen evler, sakinlerinin mezarı oldu. Tmogvi bile ylkaldı. Yeryüzünün bu sarsıntısı ve yıkılışı bütün sene devam etti ve bu süre içinde pek çok insan öldü." "40

XI. yüzyılın sonlarında doğru Antakya Şehri’nde büyük bir deprem yaşanmış ve olay, şehir halkının büyük zarar görmesine sebebiyet vermiştir. Kaynaklar olayın yaşandığı günün tarihlenmesi konusunda hemfikir olmasalar da depremin 1091 yılının Eylül ile Aralık ayları arasında meydana geldiğine dair genel bir kanı mevcuttur. Ermeni tarihçisi Mateos olayı kısaca şöyle anlatmıştır: "540 (27 Şubat 1091-26 Şubat 1092) yllının Eylül ayında bütün memleket içinde bir zelzele oldu. Yeryüzü şiddetle sarsıldı ve gök altında bulunan bütün mahlûklar titredi. Antakya Şehri'nde büyük tahribat oldu. Birçok kuleler temelden kopup yere düştü ve surun büyük kısmı yıkıldı. Erkek ve kadın birçok insan yıkılan evlerin altında can verdi. "41 İbnü'l-Esîr de Antakya depremine eserinde yer vermiştir. Ona göre: "H.484 (1091/1092) yllının 9 Şaban (26 Kasım 1091) günü Suriye ve pek çok ülkede çok sayıda deprem oldu. Ekserisi Suriye'de meydana geldi. Halk, evlerini yurtların terk etti. Antakya'da birçok ev yıkıldi; enkaz altında kalan pek çok kişi öldü, ayrıca Suriannadaki doksan burç yıkıldı. Sultan Melikşah bunların yapılmasını emretti." ${ }^{42}$ Ahmed bin Mahmud'a göre: “Deprem, H. 484 yılının Şaban ayında yani Eylül 1091'de meydana geldi ve depremi tarif edebilmek için onun gibi bir zelzele hiçbir zaman vuku bulmamış ve görülmemişti. Halkının kalbine korku ve dehşet doldu ve Antakya Hisarı'nın çoğu yıkıldı ve doksan burcu yerle bir oldu. "43 Azîmî, depremde ortaya çıkan bir tılsımı ön

\footnotetext{
${ }^{38}$ Süryani Patrik Mihail Vakainamesi, s. 38.

${ }^{39}$ Arslantaş, İslam Dünyasında Depremler ve Algılanma Biçimler, s. 84.

${ }^{40}$ Brosset, Gürcistan Tarihi, s. 309.

${ }^{41}$ Urfalı Mateos Vekayi-Nâmesi, s. 177; Simbat vuku bulan depremin Nusaybin ve Antakya'da büyük zayiata neden olduğunu söyler. Başkumandan Simbat Vekayinamesi, s. 47.

${ }^{42}$ İbnü'l-Esîr, El Kâmil Fi't-Tarih, C.X., s. 17; İbn Kesîr, El Bidaye Ve'n-Nihaye, C.XII., s. 274,275.

${ }^{43}$ Ahmed bin Mahmud, Selçuk-Nâme, Haz. Erdoğan Merçil, İstanbul 1997, s. 161.
} 
plana çıkarmakta ve olaydan kısaca bahsetmektedir. Ona göre: "1091 / 92'de Suriye'de deprem oldu; Antakya surları ve kiliseleri yıkıldı. Surun temelinde, taştan oyulmuş bir su kurnası içinde bir Frank tılsımı ortaya çıktı." "44 Cenâbî, diğer Arap kaynaklarının aksine depremin Şaban değil Şevval ayında yaşandığını iddia eder. Ona göre: "Yağıbasan zamanında Antakya'da 484 yılının 19 Şevval Pazartesi (4 Aralık 1091) gecesi büyük bir zelzele oldu. O gün Teşrîn-i evvel'in 6. gününe (6 Ekim) müsadiftir. Zelzele halktan pek çok insanın ölümüne ve evlerin yıkllmasına sebep oldu. Ayrıca surların 70 burcu da ylkıldl. Zelzelenin Suriye’de yaptığı tahribat daha büyüktü. 485 (1092) yılında Sultan Melikşah Antakya surunun ylkılan kisımlarının tamir edilmesini emretti. Tamir sırasinda surun altında Hristiyan resimleri ve silahlar bulundu. Yağıbasan, bunların tekrar gömülmesini ve olduğu gibi bırakılmasını emretti." ${ }^{5}$ Süryani Mikhail depremi kısaca şöyle anlatmaktadır: "Frankların İstanbul'u muhasara ettikleri esnada Antakya bir zelzele yüzünden yıkıldl. Ylkılan bir kulenin temelleri altında içinde büyük tunç heykeller bulunan bir yeraltı evi ortaya çıtktı. Bu heykeller, ata binmiş zırhll, mızraklı ve kılıçlı Frankları andırıyordu. Bu heykeller, zincire vurulmuş olduğu halde oraya bağlanmıştı. Türk Sultanı Aghousian (Yağıbasan), bunun hakkında tetkik yapılmasını emretti. Bunların orada niçin bulunduğunu bilen ne bir adam ne de bir yazı bulundu. Bunun üzerine, onların, putperestlerin zamanından kalmış putlar olduğu zannedildi. Bundan dolayı hepsi, sultanın emri ile kırıldı. Sonra kör ihtiyar bir kadın çıkıp: "Frankların çıkıp denizi aşmalarına mani olmak üzere kulenin birisinin altında tılsımlar bulunduğunu” eski adamlardan duymuş olduğunu söyledi. Vali, bu sözleri ihtiyar kadının ă̆zından bizzat işittikten sonra onları kırdı̆̆ına pişman oldu ve kadına: "Onların nasıl yapıldığını işitmiş miydin? Onları tekrar yapabilir miyiz ?” diye sordu. "46 İbnü’l-Kalânisî, Şam Bölgesi için depremin büyüklüğünü ve depremin şiddetini tarif ettiği büyük - şiddetli, korkunç gibi kelimelerle yetinmeyerek "daha önce böyle bir depremin vuku bulduğu duyulmamıştır" ifadeleri ile de pekiştirmiş ayrıca şehrin yetmiş burcunun yıkıldığını da belirtmiştir. ${ }^{47}$

\section{C) XI. Yüzyılda Yaşanan Kıtlık, Salgın Hastalıklar ve Çekirge İstilaları}

Aslında birbirinden bağımsız birer doğal afet veya felaket olarak düşünülen kıtlık, salgın hastalıklar ve çekirge istilaları, toplumlara yaşattıkları olağandışı durumlardan dolayı

\footnotetext{
${ }^{44}$ Azîmî, Azîmî Tarihi, s.32 ( s.119).

${ }^{45}$ Muharrem Kesik, “Cenâbî’ye Göre Türkiye Selçukluları”, İstanbul Üniversitesi Edebiyat Fakültesi Tarih Dergisi, (İstanbul 2000), sy. 36, s. 233,234.

46 Süryani Patrik Mihail Vakainamesi, s. 39,40-44,45.

${ }^{47}$ Arslantaş, İslam Dünyasinda Depremler, s. 85.
} 
tarihî kaynaklarda isimlerinden sıkça bahsettirmişlerdir. Tarih boyunca dünya üzerindeki bütün toplulukları dönem dönem yoğun bir şekilde etkileyen ve sayısız insan ölümüne veya büyük göç olaylarının yaşanmasına sebebiyet veren bu felaketler, XI. yüzyıl süresince Anadolu Coğrafyası'nda yaşayan halkları da derinden etkilemişlerdir. Coğrafya üzerindeki halklar, istilalar veya yağma olayları ile çekirge sürülerinin ekinleri yemek ve mahsulleri yok etmek suretiyle yaratmış olduğu kıtlıkla mücadele etmeye çalışırken daha büyük felaketlerin oluşumuna zemin hazırlayan yokluk ve sefaletle yaşamaya mecbur kalmışlardır. Bölge halkı bu olumsuzluklara ek olarak yokluğun meydana getirmiş olduğu ölüm vakaları sonucunda türeyen salgın hastalıklar ile mücadele etmişlerdir. Ancak çoğu zaman bu felaketlerin karşısında çaresiz kalan topluluklar büyük göç hareketleri ile yaşanabilecek yeni yerler aramaya başlamışlar; fakat bu hareketlenme ile de kendisine yayılma imkânı bulan salgın hastalıklar kitlesel ölüm olaylarına sebebiyet vermiştir.

Sayısız insan ölümün müsebbibi olan bu felaketlerin başında gelen kıtlık olayı, Anadolu'da 1032 / 1033 yılında yaşanmış ve bu vaka gerek Ermeni gerekse Bizanslı tarihçiler tarafından kaleme alınan eserlerde kendilerine yer bulmuştur. Birçok farklı doğa olayına kayıtlarında yer veren tarihçi Mateos, bu yüzyılda yaşanan büyük kıtlık olaylarından da söz etmektedir. Yazarın aktardıklarından anlaşıldığı kadarıyla 1032 / 1033 tarihinde her tarafta şiddetli bir kıtlık olmuş ve birçok insan ölmüştür. Felaketzedeler yiyecek yokluğundan dolay1 hanımlarını ve çocuklarını satmışlar. İnsanlar o kadar elim bir hâle gelmişlerdi ki konuşurken bile düşüp düşüp ölmüşler ve sonucunda yeryüzü kıtlık sebebiyle bir viraneye dönmüş. ${ }^{48}$

Bizanslı tarihçi Skylitzes de 1032 yılında Anadolu'da yaşanan kıtlık ve salgın hastalıklar hakkında bilgi vermektedir. Tarihçinin malumatlarına göre: "Kapadokya, Paphlagonia, Armeniakon themast ve Honoriad'l kıtlı ve salgın hastalıklar etkiledi. Bu themaların halkları yaşamak için yeni yerler aramak amacıyla atalarının topraklarını terk ettiler. Imparator, bu göçün doğurabileceği sonuçtan habersiz, Mesanakata'dan başkente geri dönüşü sırasında göçmenlerle karşılaştı; onları evlerine geri dönmeleri için zorladı ve onlara para verdi ardından yaşamlarını sürdürebilmeleri için diğer ihtiyaçlarını tedarik etti." 49 Tarihçi Zonaras da 1032 yılında yaşananlardan kısaca şöyle bahsetmiştir: "Kappadokia, Armeniakon ve Paphlagoia yöreleri kutllktan eziyet çekmekte olduğu ve buraların çekirge

\footnotetext{
${ }^{48}$ Urfalı Mateos Vekayi-Nâmesi, s. 58; Başkumandan Simbat Vekayinamesi, s. 23.

${ }^{49}$ Skylitzes, A Synopsis of Byzantine History, s. 364.
} 
istilasına uğradiğl için pek çok insan yurdunu terk etmek zorunda kaldl, ancak bunlar imparatordan parasal destek almalarının ardından geri dönmeye ikna edildiler. " 50

Yaşanan vakalar hakkında bilgi vermeye devam eden Skylitzes, 1034 yılı içerisinde Doğu vilayetlerinin çekirge salgınından dolayı büyük zarar gördüğünü söylemiş ve bu eyaletlerinin halklarının Trakya'ya göç etmek veya çocuklarını satmak zorunda kaldıklarını iddia etmiştir. ${ }^{51}$ Yazara göre yine aynı y1l içerisinde Hellespont sahilinde yok olduğu söylenen çekirge sürüsü yeniden kendiliğinden türedi ve tekrar Hellespont Bölgesi'nin sahilini kapladı ve üç yıl boyunca Thrakesion themasini tahrip etti. ${ }^{52}$

Bizanslı tarihçiler, 1078 yılında İstanbul'da çok büyük bir kıtlık yaşandığını iletmektedir. Zonaras ve Attaleiates bu kıtlık olayını şöyle anlatmaktadır: "İnsanlar gerçek anlamda açlıktan ölüyorlardı ve sanki bunlar yetmezmiş gibi ardından veba çıtkt. Sonuçta pek çok insan, birbiri ardınca öldü; öyle ki canlı kalanlar ölüleri gömmeye yetişemiyordu. Bu ölüler o kadar çok sayıdaydı ki sık sık birden çok kişiyi (çoğu kez aynı tabut içinde beşi yahut altısı bir arada hiçbir özen göstermeden rastgele bir yük yahut hayvan leşi taşır gibi) tek bir tabut içinde gömdüler ve meydanlar cesetlerle doluydu." 53

Tarihçi Mateos 528 (2 Mart 1079/29 Şubat 1080) tarihinin başlangıcında Okyanus denizinin beri kıyısında bulunan Hristiyan memleketlerinde şiddetli bir kıtlık yaşandığını ifade etmektedir. Yazar, yaşanan bu kitlık olayının müsebbibi olarak Türkleri görmüştür. Kendince bu düşüncesini haklı çıkarmaya çalışan yazara göre: "Türkler bütün memlekette yayılmış ve hiçbir bölgede sulh ve asayiş kalmamıştı. Toprak işlenmedi ve ekmek azaldı. Çalışkan çiftçiler kılıç ve esaretle telef oldu ve bütün memlekete yayıldı. Birçok eyaletler ıssız bir hâle geldi. Şark milleti mahvoldu ve Roma memleketi bir viraneye çevrildi. Urfa ile havalisinden başka hiçbir yerde insanlar ne ekmek ne de rahat edecek bir yer bulamiyorlardl. Antakya, Tarsus'a kadar Kilikya'da Maraş’ta Deluk'da ve bu yerlerin bütün havalisinden insanlar rahat yüzü

\footnotetext{
${ }^{50}$ Ioannis Zonarae, Epitomae Historiarum, s. 580,581; Zonaras, Tarihlerin Özeti, s. 52,53.

${ }^{51}$ Skylitzes, A Synopsis of Byzantine History, s. 367.

${ }^{52}$ Skylitzes, A Synopsis of Byzantine History, s. 372.

${ }^{53}$ Ioannis Zonarae, Epitomae Historiarum, s. 714,715; Zonaras, Tarihlerin Özeti, s. 148; Abû'l-Farac'a göre H.470 ve Yunanlıların 1389 (1078) yılında Süleyman Şah ile Botaneiatés'in İstanbul'u kuşattıkları bir sırada İstanbul'da altı ay kadar yaman bir kıtlık hüküm sürmüş, kıtlığın ardından ise veba da baş göstermiştir. Ölüleri kaldırarak büyük kilisedeki ölüler yerine getiren adam, burasının dolması üzerine kilisenin denize açılır kapısından cesetleri denize atıyordu. Abû'l-Farac, Abû'l-Farac Tarihi, s. 328; Attaleiates, Botaneiatés'in Türklerle İstanbul'u kuşattığı bir sırada herkesin gözü önünde bir mucizenin gerçekleştiğini söyler ve olayı şöyle anlatır: "Gecenin birinci nöbet vaktinde doğu tarafından maddesiz bir ateş belirdi. Bu ateş, bir kaynaktan fişkırıyor ve havaya dağılıyor gibiydi. O zaman hava, parlak alevlerle doldu ve ateş ırmağı, Kadıköy ve Üsküdar’a kadar herkesin şaşkınlığına yol açarak aktı.” Bu kayıtlar Bilge Umar'ın da dediği gibi dönem yazarlarının Hükümdarlarını yüceltmek için yaptıkları masalsı
} anlatımlardır. Michaelis Attaliotae, Historia, s. 211,212; Attaleiates Tarih, s. 213, 239, d.n. 167. 
göremediklerinden dolayı oralardan kalkarak buralara (Urfa) geliyorlardı. Açlık ve yurtsuzluk yüzünden, memlekette ölüm vakaları o kadar çoğaldı ki ölüleri defnedecek takat kalmadl. Bundan dolayı cesetler yeryüzünde yığın hâlinde kaldı ve vahşi hayvanlarla yırtıcı kuşlar onları yemekten usandı. Bu adil ve hakim olan Tanrı'nın günahlarından dolayı Ermenilere verdiği bir ceza idi..$^{54}$

Yaşanan kıtlık ve ölüm olayları ile alakalı bilgi vermeye devam eden Ermeni yazarların anlattıklarına bakılırsa 541 (27 Şubat 1092 - 25 Şubat 1093) tarihinde çok fazla sayıda ölüm vakası olmuş, hatta papazlar ölüleri gömmeye vakit bulamamışlardır. Hristiyan yazarlara göre hemen her evden ağlayış sesleri ve figanlar yükseliyordu. Ölüm vakaları o kadar çoğaldı ki birçok insan, korku ile sarılıp can vermekte olanlardan daha ziyade azap duyuyorlard1. Simbat, bu olaya dair, bütün memlekette bir ölümün (veba) zuhur ettiğini ve ölü sayısı çok olduğu için onları defnetmenin zorluklarından bahsetmiştir. Vardan'a göre aynı yıl çekirge ve kuraklık yüzünden müthiş bir kıtlık yaşanmıştır. Hatta Ani Şehri'nde ölülerin çokluğundan duyulan üzüntüden dolayı ölüler, nizami zaruri olan dinî merasimler bile yapılmadan defnedilmiştir. ${ }^{55}$

XI. yüzyılın sonlarına doğru Antakya Şehri ve çevresinde yeni bir kıtlık ve ardından da salgın hastalık, I. Haçlı Seferi sırasında şehri kuşatan Haçlı Orduları arasında baş göstermiştir. Kuşatma sırasında Haçlı komutanlarından Bohemund ve Robert, 28 Aralık 1097 tarihinde yiyecek bulmak amacıyla çevre bölgelere yaptıkları akınlardan elleri boş bir şekilde Antakya karargâhına döndüklerinde arkadaşlarını büyük bir maneviyat kırıklığı içinde buldular. Çünkü 29 Aralıktaki meş'um gece savaşından sonra ertesi gün, öyle ki Urfa'da bile hissedilen şiddetli bir deprem olmuş; bunun gecesinde fecri şimâlî (Kuzey Işı̆̆ı) gökyüzünü aydınlatmıştı. Bunu takip eden haftalarda durmadan tufanı andıran yağmurlar yağdı ve hava gittikçe soğudu. Erzak temini için düzenlenen seferin de sonuçsuz kalması gelecekte baş gösterecek olan açlık tehlikesinin bir işaretiydi ve bu, birçok askerin açlıktan ölmesi demekti. Ne var ki kısa bir zaman sonra ordunun yedide biri açlıktan öldü. Haçlı Ordusu'nun maruz kaldığı açlık o kadar

\footnotetext{
${ }^{54}$ Urfalı Mateos Vekayi-Nâmesi, s. 155,156; Başkumandan Simbat Vekayinamesi, s. 45; Süryani Mihail yaşanan bu kıtlığın yılını 1082 olarak vermektedir. Süryani Patrik Mihail Vakainamesi, s. 38; Sibt İbnu'l-Cevzî, Bölgede meydana gelen kıtlığın olumsuz sonuçlarını Şam Şehri'nin içinde bulunduğu durumu anlatarak özetlemiştir: "500 bin nüfuslu Dimaşk'ta sadece 3 bin kişi kalmıştı, çünkü halk, fakirlik ve pahalıllk nedeniyle şehirden göç etmişti. Şehirde 240 ekmek firını varken şimdi sadece iki firın kalmıştı. Kent sokakları bomboş idi; 3 bin altın değerinde olan bir ev, 10 altına satılmak üzere, münadiler bağırlyor, fakat hiç kimse almıyordu. Zaylf ve fakir insanlar, değeri çok az olan evlere gidip tahta kısımlarını yakmak suretiyle ısınıyorlar, şehrin dar sokaklarına gidip buradan geçen kedi ve köpekleri yakalayarak boğazliyorlar, etlerini keserek kizartıp yiyorlardl.” Sibt İbnu'l-Cevzî, Mir'âtü'z-Zamân Fî Târîhi'l-Âyân'da Selçuklular, Seçme Türcüme ve Değerlendirme Ali Sevim, TTK. Yay., Ankara 2011, s. 214.

55 Urfalı Mateos Vekayi-Nâmesi, s. 177; Başkumandan Simbat Vekayinamesi, s. 47; Vardan, Türk Fütuhatı Tarihi, s. 185.
} 
şiddetliydi ki askerler, ölü Müslüman askerlerinin gömülü naaşlarını çıkartıp yemişlerdir. Gerçekte, takip eden kış koşulları çok ağırdı. Kuşatmadaki zayiat azdı belki ancak çok sayıda asker hastalandı ve çokları da öldü. Hastalıklar yüzünden ordu içinde muharip olmayanların sayısı çoğaldı. Feda Şamil Arık, bu sırada ortaya çıkan ve birçok askerin ölümüne neden olan hastalığın, veba olduğunu iddia etmektedir. ${ }^{56}$ Ancak uzun ve zor bir kuşatma sürecinden sonra Antakya'ya giren Haçlı Ordusu, şehrin Rum ve Ermenileri ile işbirliği yaparak ele geçirdikleri Türk, kadın ve çocuk demeden herkesi ölürdüler. Öyle ki 3 Haziran akşamı olurken Antakya'da canlı hiçbir Türk kalmamıştı. Şehrin sokaklarında sıcak yaz gününde süratle kokmaya başlayan cesetler hızla temizlendi. Ancak Temmuz ayı içerisinde Antakya'da şiddetli bir salgın hastalık çıktı. Hastalığın ne olduğu tam olarak bilinmemesine rağmen tifüs veya veba olduğu düşünülmekte idi. Salgın hastalık yayılırken ileri gelen Haçlı reisleri, kurtuluşu açık arazilere kaçmakta buldular. Eylül ayı içinde salgın hastalık gücünü yitirince de Haçlı reisleri Antakya'ya geri döndüler. ${ }^{57}$

D) XI. Yüzyılda Yaşanan Sıra Dışı Gökyüzü Olayları ve Bu Olaylara Yüklenen

\section{Anlamlar}

XI. yüzyılda Anadolu'da meydana gelen doğal afetlere ek olarak yoğun şekilde sıra dışı gökyüzü olaylarına da rastlanmak mümkündür. Ayrıca bu vakalar canlı tasvirlerle tarihî kaynaklarda kendilerine yer bulmaktadırlar. Bu yüzyılda meydana gelen gökyüzü olayları ile alakalı en eski bilgiler Arap yazarlar İbn Kesîr ve İbnü'l-Esîr'e aittir. İbn Kesîr'e göre: “H.392 (Eylül / Ekim 1002) yılının Zilkade ayının üçünde pazartesi gecesi gökten bir yıldız düştü, etrafi gece boyunca ay gibi aydınlattı. Sonra ışı̆̆ı gitti, ama cirmi $2 \times 2$ zira' boyutunda gözle görünür şekilde dalgalandl. Bir saat sonra da kayboldu." İbnü'l-Esîr bu yılın olaylarını şöyle anlatmaktadır: "1002 / 1003 Bu yılın ramazan ayında (Temmuz / Ăgustos) büyük bir kuyruklu yıldız doğdu. Aynı yıl zilkade ayında da aynı şekilde büyük bir yıldız kaydı. Dolunay gibi ışık saçıyordu. ${ }^{, 58}$

Tarihçi Mateos, 1003 / 1004 yılında yani Bizans İmparatoru Vasil (II. Basileios 976 1025) döneminde, gökte felaketleri ve dünyanın sonunu işaret eden aleve benzer bir yıldız

\footnotetext{
${ }^{56}$ Feda Şamil Arık, "Selçuklular Zamanında Anadolu'da Veba Salgını" Ankara Üniversitesi Dil ve Tarih-Coğrafya Fakültesi Tarih Bölümü Tarih Araştırmaları Dergisi Cilt: 15 Sayı: 26, Ankara 1991, s. 45.

${ }^{57}$ Steven Runciman, Haçlı Seferleri Tarihi, Birinci Haçlı Seferi ve Kudüs Krallı̆̆ııın Kuruluşu, C.I., çev.: Fikret Iş1ltan, TTK Yay., Ankara 2008, s. 170,180,194,196,197; Urfalı Mateos Vekayi-Nâmesi, s. 192, d.n. 214; David Nicolle, Birinci Haçlı Seferi 1096-99, çev.: Ece Sakar, İş Bak. Kültür Yay., İstanbul 2010, s. 53; Anonim Haçlı Tarihi, çev.: Ergin Ayan, Selenge Yay., İstanbul 2013, s. 88.

58 İbn Kesîr, El Bidaye Ve'n-Nihaye, C.XII., s. 25,26; İbnü'l-Esîr, El Kâmil Fi 't-Tarih, C. IX., s. 146,147.
} 
ortaya çıktığını söylemektedir. Yazar, her yerde şiddetli zelzele olduğunu belirtirken kayıtlarında insanların, düşüncelerine ve korkularına yer vermiş, ardından sözlerine şöyle devam etmiştir: "Birçok adam dünyanın sonunun gelmişs olduğunu zannettiler. Herkes tufan zamanında olduğu gibi titremeye başladl. Insanlar korku ve dehşet yüzünden günahlarını çıkartmaya ve "communion" almaya vakit bulamiyorlard. Insan ve hayvanlar telef oldu. Sahipsiz kalan hayvanlar başıboş dolaşıyorlardı." Simbat, Mateos'un aksine bu olayın 457 (1008 - 1009) tarihinde meydana geldiğini söylemektedir. ${ }^{59}$

Abû'l-Farac, yüzyılın ilk yıllarında ortaya çıkmış olan bir kuyruklu yıldızdan bahseder. Ona göre: “H. 396 (1005 - 1006) yllında büyüklügü ve ihtişamı bakımından Afrodit'e benzeyen bir yıldız, akrep burcunda göründü. Şuaları dönüyor ve ay ışı̆̆ına benzeyen bir ışık veriyordu. Bu hâl dört ay kadar devam etti sonra zail oldu. ${ }^{\prime 60}$ Bu olay, İslam kaynaklarında şöyle geçer: "H. 396 (Mayıs 1006) yılının Şaban ayının başında bir cuma gecesi büyüklük ve fazla ışık saçıcı olması bakımından Zühre yıldızını andıran bir yıldız kıble cihetinin sol tarafinda dalgalı bir hâlde doğdu. Ay gibi yeryüzünü aydınlattı ve Zilkade ayının ortalarına kadar gökte göründü. Sonra kayboldu. " 61

İbn Kesîr, H.403 (Mart / Nisan 1013) y1lının Ramazan ayında doğu tarafindan bat1 tarafına ay 1şı̆̆ı gibi 1şık saçan, sonra gökte paramparça olan ve bir müddet gökte duran bir yıldız görüldüğünü söylemektedir. ${ }^{62}$ İbnü’l-Esîr ise H.417 (Ekim / Kasım1026) yılının Ramazan ayında büyük bir yıldız kaydığını; onun etkisiyle yeryüzünün aydınlandığını ve kayarken yıldırım gibi bir ses çıkardığını ifade eder. ${ }^{63}$

Tarihçi Simbat, Ermeni takvimine göre 478 (1029 - 30) tarihinde İmparator Vasil'in (Basileios) hâkimiyeti zamanında gökyüzünde korkunç bir nişanenin ortaya çıktığını belirmiştir. Ancak İmparator Basileios, 967 - 1025 yılları arasında hüküm sürmüştür ve Simbat'ın, aynı yılda imparatorun öldüğünü söylemesi, bu olayın 1025 yılında meydana geldiğini ortaya çıkarmaktadır. Yazara göre: “Gökyüzü yarılmış gibi görünmüş ve yere fevkalade parlak bir ışık inmiştir. Herkes, bu ışı̆̆ın akışından dolayı büyük bir korku içine düşmüş. Bunun üzerine Hovannes Gozern'in yanına gidilmiş ve bu korkunç nişanenin manası sorulmuş, o da gözyaşları

\footnotetext{
${ }^{59}$ Urfalı Mateos Vekayi-Nâmesi, s. 47; Başkumandan Simbat Vekayinamesi, s.17.

${ }^{60}$ Abû'l-Farac, Abû'l-Farac Tarihi, s.279.

${ }^{61}$ İbn Kesîr, El Bidaye Ve'n-Nihaye, C.XII., s. 34; İbnü'l-Esîr, El Kâmil Fi't-Tarih, C.IX., s. 155,156.

${ }^{62}$ İbn Kesîr, El Bidaye Ve'n-Nihaye, C.XII., s. 53-55.

${ }^{63}$ İbnü'l-Esîr, El Kâmil Fi't-Tarih, C. IX., s. 277,278; İbn Kesîr, El Bidaye Ve'n-Nihaye, C.XII., s. 84,85.
} 
dökerek, son zamanlarda işlenen fenalıklardan dolayı memleketin uğrayacă̆ı felaketlerden bahsetmiștir. ${ }^{\prime 64}$

İslam tarihçilerinin eserlerinde, H.420 yılının Recep ayı içerisinde (Temmuz / Ağustos 1029) büyük bir yıldız kaydığına dair kayıtlar mevcuttur. Kaynaklarda bu vaka şöyle tasvir edilmiştir: "Yeryüzü aydınlandı ve gök gürültüsüne benzer büyük bir ses işitildi, yıldız dört parçaya ayrıldı. Bundan iki gece sonra başka bir yıldız kaydl. Bir süre sonra bu iki yıldızdan daha büyük ve daha parlak bir yıldız kaydı." 65

Bizanslı tarihçi Skylitzes, dört yıl içerisinde üç farklı gökyüzü olayının yaşandığını belirtmiştir. Bunlardan ilki, Ekimin otuz birinde (31 Ekim 1029) batıdan doğuya doğru bir kayan bir yıldız. ${ }^{6}$ Devamında 28 Temmuz 1032 Cuma günü, gecenin ikinci saatinde güneyden kuzeye doğru bir yıldızın kayması ki yazar, bu sırada bütün dünyanın aydınlandığını iddia eder ve bu olayı aslında bir felaket habercisi olarak da görür; çünkü çok kısa zaman sonra Roma İmparatorluğu'ndan üzücü felaket haberleri gelmeye başlamıştır. Bu olaydan yaklaşık yedi ay sonra 20 Şubat 1033 tarihinde bir yıldız, kuzeyden güneye doğru sesli ve gürültülü bir şekilde geçmiş; ardından yıldız, 15 Mart tarihine kadar gökyüzündeki yerini korumuştur. ${ }^{67}$

Skylitzes'in belirttiği gökyüzü olaylarının ardından İslam tarihçileri de H. 425 yılının Zilkade (Eylül / Ekim 1034) ayında görünüşü insanlara ürperti veren bir yıldızın kaydığııı ifade ederler ve bu olaydan iki gece sonra da ondan daha büyük başka bir yıldızın kaydığını belirtirler. Tarihçiler: "Yıldız, adeta yeryüzüne yapışmış bir şimşek gibiydi. Lambaların ışığı onun parlaklı̆̆ yanında sönük kaldı. Yıldız uzun süre kaldıktan sonra kayboldu." demektedirler. $^{68}$

Gökyüzü olayları hakkında bilgi vermeye devam eden Skylitzes, 1034 yılına dair kayıtlarında da yıldız kaymasından bahseder ve aktarımlarına şöyle devam eder: "Easter (Paskalya) gününden sonraki pazar, gecenin üçüncü saatinde bir yıldız kaymış, onun ışıklarlyla bütün yıldızlar parlamış hatta çoğu için güneş doğmuş gibi görünmüştür." ${ }^{9}$ Yine ayn yılın Eylül ayında doğuda bir ateş sütunu göründü. Daha sonra zirvesi güneye doğru eğildi. ${ }^{70}$

\footnotetext{
${ }^{64}$ Başkumandan Simbat Vekayinamesi, s. 21.

${ }^{65}$ İbnü'l-Esîr, El Kâmil Fi 't-Tarih, C.IX., s.302-304; İbn Kesîr, El Bidaye Ve'n-Nihaye, C.XII., s. 104,105.

${ }^{66}$ Skylitzes, A Synopsis of Byzantine History, s. 356.

${ }^{67}$ Skylitzes, A Synopsis of Byzantine History, s. 364,365.

${ }^{68}$ İbnü'l-Esîr, El Kâmil Fi 't-Tarih, C. IX., s. 335,336; İ̉n Kesîr, El Bidaye Ve'n-Nihaye, C.XII., s. 120.

${ }^{69}$ Skylitzes, A Synopsis of Byzantine History, s. 371.

${ }^{70}$ Skylitzes, A Synopsis of Byzantine History, s. 374.
} 
Farklı doğa olayları hakkında sıkça bilgi veren tarihçi Mateos, kayıtlarında sıra dışı gökyüzü olaylarına da yer vermiştir. Yazar: "485 yılında (1036 / 1037) güneş tutuldu ve korkunç bir manzara hasıl dolu. Zira güneş, Hz. İsa'nın çarmıha gerildiği sırada olduğu gibi karanlıkla örtüldü ve bir matem karası içine girdi. Yıldızlar karardı ve gök, siyah bir kemerle çevrilmiş gibi karanlık içine düştü. Güneş, tam öğle vakti karardı ve bütün yıldızlar gece yarısı gibi parlamaya başladı. Karanlık o kadar tekâsüf etti ki bütün mahlûkatlar haykırmaya başladılar. Bütün dağlar, tepeler çınladı. Bütün dă̆ ve kayalar sarsıldı. Büyük okyanus denizi çalkalanıyor ve sanki matem içine girip bütün insanoğlu için ağllyordu. Insanlar bu dehşetli nişaneye karşı şaşkınlık ve korkuya tutulmuş bir vaziyet içinde bulunuyorlardı. Bu büyük alamet hakkında izahat almak isteyen Ermeni ileri gelenleri, rahip Hovannes Gozern'e bir heyet gönderdi. Rahip, gelen heyete bütün Hristiyan milletlerin akbeti için duyduğu derin actyı anlattı. Hovannes, yaklaşık on dört yıl önce keşfedip söylemiş olduğu bir alametin aynısının yeniden tekrar ettiğini söylemiştir." diye iddia da bulunmuştur. Genel anlamda Hristiyan toplumu ve ruhani sınıf içerisinde bozulmaların olacağını söylemiş ve sözlerine kısaca şöyle devam etmiştir: “Bu zamanda Müslümanların taarruzları vuku bulacak. Ham'ın oğulları olan Türk askerleri, Hristiyan milletlerin üzerine gelecekler; bütün memleketi kılıçla tahrip edecekler ve bütün Hristiyanlar, açlık ve esaret yüzünden mahvolacaklardır. Birçok kiliseler temellerinden yıkılacak ve Hz. İsa'nın haçının hikmeti lağvolacaktır. "71

Mateos'a göre: “489 (11 Mart 1040 - 10 Mart 1041) tarihinde gökte, bir meşale gibi parlayan kuyruklu bir yıldız belirdi. Yıldız, akşamleyin garp tarafinda geriye doğru sürüklenerek, Ülker burcuna ve aya rastladl. Sonra da tekrar garp tarafina gelip gözden kayboldu." 72

Skylitzes, 11 Ekim 1042'de bir kuyruklu yıldızın doğudan batıya doğru giderken görüldüğünü ve bütün ay boyunca parladığını belirtir. Tarihçi, diğer Bizanslı yazarlar gibi yaşanan bu doğa olayını ileride meydana gelecek dünya çapında bir felaketin kehaneti olarak görmüştür. ${ }^{73}$

Azîmî, XI. yüzyılın ortalarında iki farklı gökyüzü olayından bahsetmiştir. Ona göre: “1052 / 1053 yılında semada süratle hareket edip seyreden bir yıldı göründü sonra kayboldu

\footnotetext{
${ }^{71}$ Hovannes Gozern'in bahsetmiş olduğu ondört yıl önceki nişane, muhtemelen İmparator Basileios'un öldüğü 1025 yılında görülen kuyruklu yıldız vakasıdır. Urfalı Mateos Vekayi-Nâmesi, s. 59-64; Başkumandan Simbat Vekayinamesi, s. 23.

${ }^{72}$ Urfalı Mateos Vekayi-Nâmesi, s. 67; Başkumandan Simbat Vekayinamesi, s. 24.

${ }^{73}$ Skylitzes, A Synopsis of Byzantine History, s. 399.
} 
ve depremler arttı. Yaklaşık üç yıl sonra 1055 / 56 yılında yuvarlak kıvllcımlar saçan kuyruklu bir yıldız göründü."’74

İbnü'l-Esîr, 1055 ile 1065 yılları arasında yaşanan sıra dışı gökyüzü olayları ile ilgili olarak düzenli bir şekilde bilgi vermektedir. Tarihçinin verdiği bu kayıtları doğrular şekilde benzer olaylar diğer İslami yazarlarda da mevcuttur. Kaynaklara göre: "H.448 yılının Cemaziyülâhır ayının ikinci yarısında (Ă̆ustos / Eylül 1056) seher vaktinde gökte göz kararıyla yaklaşık on arşın uzunluğunda ve bir arşın genişliğinde beyaz bir kuyruk zuhur etti. Recep ayının ortalarına kadar bu şekilde kaldı ve daha sonra ortadan kayboldu. H. 452 yıl içinde Cemaziyülevvel 'in üçüncü günü (Haziran / Temmuz 1060) şafak sökerken batıdan doğuya doğru büyük bir yıldız kaydı ve uzun süre gökyüzünde kaldı. H. 453 yılının Cemaziyülevvel (Mayıs / Haziran 1061) ayında ayın bitimine iki gece kala güneş tamamen tutuldu, insanlar dört saat öylece beklediler öyle ki ylldızlar gözüktü; dünya kapkaranlı oldu ve bu yüzden kuşlar yerlere düştü. H. 456 (1063 / 1064) yılında büyük bir yıldız kaydl ve yeryüzünü aydan daha fazla aydınlattl. Büyük bir gürültü duyuldu ve daha sonra kayboldu. H. 457 (1064 / 1065) yılında büyük bir yıldız kaydl. Aydan daha çok ışı̆̆ı vardı. Bu sırada korkunç bir ses işitildi. "75 İslami yazarlar, yaşanan bu olayları herhangi bir vakanın nişanesi olarak görmemiş veya geleceğe dönük kehanetler olarak yorumlamamışlardır. Müslüman yazarlar, bu yaşananları sıradan bir gökyüzü olayı şeklinde algılamış ve olabildiğince de sade bir anlatımla kaleme almışlardır. Aksine Hristiyan yazarlar, bu tarz olayları ilahi bir sebep - sonuç ilişkisi içerisinde yorumlamışlardır. Örneğin tarihçi Mateos, benzer bir gökyüzü olayını şöyle kaleme almıştır: "1066 / 67 yllının başlarında şark tarafinda beliren ve garba doğru yürüyen kuyruklu bir yıldız görüldü. Devamında yıldız, bir ay göründükten sonra gözden kayboldu. Birkaç gün sonra o, akşam vaktinde garp tarafindan tekrar göründü. Bunu görenler, yıldızın Müslümanların gelip de Ermenistan'ı yağma ve tahrip ettikleri, Hristiyanları öldürdükleri ve boyundurukları altına aldıkları zamanda şark tarafinda belirmiş olan yıldızın aynısı olduğunu söylediler." Ve bu olayı aynı zamanda İran'dan gelen Emir Afşin'in seferinin nişanesi olarak gördüler. ${ }^{76}$

$\mathrm{Bu}$ olay, İbnü'l-Esîr'de şöyle geçmektedir: “H.458 (Mart / Nisan 1066) yllında Cemaziyülevvel ayının ilk on günü içinde doğu tarafinda uzun kuyruklu bir yıldız zuhur etti.

\footnotetext{
${ }^{74}$ Azîmî, Azîmî Tarihi, s. 14,16.

75 İbnü'l-Esîr, El Kâmil Fi't-Tarih, C.IX., s. 478,479, C.X., s. 30,31-34,35-52,53-58; İbnü'l-Cevzî'den ileten İbn Kesîr'e göre: "Bu senenin (H.448) cemaziyülahır ayının ikinci onuncu gününde seher vakti kuyruklu bir yıldız görüldü. Göz tahminine göre kuyruğunun uzunluğu on zira', eni de on zira' kadardı. Bu yıldız Recep ayının ortalarına kadar semada görüldü. Sonra kayboldu.” İbn Kesîr, El Bidaye Ve'n-Nihaye, C.XII., s. 168,171-198,199.

${ }^{76}$ Urfalı Mateos Vekayi-Nâmesi, s. 133.
} 
Genişliği yaklaşık üç arşındı, gökyüzünün ortasına kadar uzanmıştı, ayın yirmi yedisine kadar kaldıktan sonra kayboldu. Ayın son günü güneş batarken aynı şekilde bir ylldız daha zuhur etti ve ay gibi çevresini aydınlattı. Halkın canı sıkıldı ve korktu. Gece olunca güney tarafindan bir kuyruğu tekrar ortaya çıtıtı ve o, on gün kaldıktan sonra kayboldu. "77

Gürcü Kroniklerinde bile kendine yer bulan bu olay, şu ifadelerle anlatılmaktadır: "Suçlarımızdan dolayı bizi cezalandıran Allah, kan yağmuru damlatan bir bulut şeklinde göründü. Bu bulut, Gürcistan'ın önemli siyasi bölgelerinden birisi olan Kartli'nin doğusuna yayılarak gün aydınlı̆̆ını derin karanlıklara çevirdi. Manzara korkunçtu, muhtelif yerlerde kan yă̆muru görüldü. " 78

Bizanslı tarihçi Zonaras ise bu olayı kısaca şöyle anlatmaktadır: "Dördüncü "taşınmaz mallarda vergi değerinin belirleme döneminin” Mayıs ayında (4 Mayls 1066) bir kuyruklu yıldız görüldü ve güneşi izleyip batıya yöneldi. Önceleri dolunaya benziyordu; ardından, sanırsın ki bir de saçları çıtktı; gittikçe büzüldü ve hatta saçları büyüdükçe aynı oranda kendisinin büyüklüğ̈̈ azald. 40 gün boyunca saç benzeri ışıları doğu yönüne dönük olarak seçilmekte idi." Attaleiates ise bu olayı biraz daha farklı dile getirmiştir: "Dördüncü "taşınmaz mallarda vergi değerinin belirleme döneminin" Mayls süre giderken (1066) güneşin batmasından sonra bir kuyruklu yıldız görünür oldu. Ayın dolunay evresindeki büyüklüğündeydi ve sanki kendisinden duman ve buğu çıklyormuş izlenimi veriyordu; ilk görünüşünün ertesi günü ip gibi bir çeşit kuyruk benzeri çıkıntılarını da belli etmeye başladı ve günden güne bunlar uzayıp genişledikçe, kuyruklu yıldızın büyüklüğü de aynı ölçüde eksildi. Bu ışınımsı çıkıntılar doğuya yönelmişe benziyorlardl; kuyruklu yıldız dahi aynı yönde hareket eder gibiydi. Bu seyir kırk gün sürdü. ",79

İbnü'l-Esîr, 1080'li yıllarda meydana gelen iki farklı gökyüzü olayından kayıtlarında bahsetmiştir. Ona göre: "H.477, M. 1084 / 1085 yllının Sefer ayında doğudan batıya doğru bir yıldız kaydı. Büyüklü̆̈̈ü ve ışığı ayınki kadardı. Daha sonra yaklaşık bir saat içinde yavaş yavaş uzaklaşıp gitti. Bundan önce buna benzer bir yıldız zuhur etmemişti.” H.480 (1087 / 1088) yılında da tam güneş tutulması oldu. ${ }^{80}$

\footnotetext{
${ }^{77}$ İbnü'l-Esîr, El Kâmil Fi't-Tarih, C.X., s. 60,61.

${ }^{78}$ Brosset, Gürcistan Tarihi, s. 291.

${ }^{79}$ Ioannis Zonarae, Epitomae Historiarum, s. 680; Zonaras, Tarihlerin Özeti, s. 119; Michaelis Attaliotae, Historia, s. 91,92; Attaleiates, Tarih, s. 99.

80 İbnü'l-Esîr, El Kâmil Fi't-Tarih, C.X., s. 130-146,147.
} 
Doğa olayları hakkında yoğun olarak bilgi veren kaynaklara ek olarak Ahmed bin Mahmud da meydana gelen bir gökyüzü olayından bahsetmiş ve bu vakayı Selçuklu Sultanı ve vezirinin ölümü ile bağdaştırmıştır. Yazara göre: "O yllın Rebiyülevvel ayının ortasında (25 Nisan 1092) Pazartesi günü, Zuhal ile Merih yıldızları Seretan (Yengeç) burcunda öyle vaktinde birleştiler. Burada şimdiye kadar böyle bir şey vuku bulmamıştı. Tesadüf o yıl Melikşah ile Nizamü'l-Mülk öldüler. Yıldızlarla uğraşanlar: "Bunun gibi büyük sultanın ve vezirin ölümü bu birleşmenin tesirindendir." dediler. "\$1 Azîmî, H.489 (1095 / 1096) yılında kuyruklu bir yıldızın doğduğunu belirtmektedir. ${ }^{82}$

İslam kaynakları, H.490 (Temmuz / Ağustos 1097) yılının Şaban ayında büyük bir kuyruklu yıldız doğduğunu ve yirmi gün süresince zuhur eden yıldızın daha sonra kaybolduğunu ve bir daha görünmediğini belirtirler. Mateos ise bu olayı şöyle aktarmaktadır: “Ermeni takvimine göre 546 (25 Şubat 1097 / 24 Şubat 1098) yılında Arek ayı içinde garp tarafinda kuyruklu bir yıldız belirdi. Bu yıldızın kuyruğu, onun ziyasını kısmen kapliyordu. Yıldız, on beş gün göründükten sonra kayboldu. Aynı yılda göğün şimal kısmında korkunç ve acayip bir nişane belirdi. Böyle hayret verici bir şey şimdiye kadar hiç görülmemişti. Mareri ayı içinde gökyüzü bir alev gibi tutuştu ve hava açık olduğu halde kızardı. Gökyüzü, sanki birbiri üzerine yığılmış tepelerle kaplandı ve rengârenk bir hâl aldı. Bu renkli yığıılar şarka doğru kaymaya başladı ve sıklaştıktan sonra dağılıp gökyüzünün büyük bir kısmını kapladı. Sonra hayret edilecek derecede olan koyu kırmızılık, gök kemerinin ortasına kadar uzandl. Âlimler, bunun kan döküleceğine dair bir alamet olduğunu söylemişlerdir. "83

Tarihçi Mateos, bu yüzyılın sonunda üç önemli gökyüzü olayından bahsetmiştir. Ona göre: "1098 / 1099 tarihinde gögü̈n şimal kısmında ikinci bir alamet belirdi. Gecenin dördüncü saatinde gökyüzü evvelkinden daha klzgın bir hâl aldl. Bu alamet, akşamdan gecenin dördüncü saatine kadar devam etti. Bu kadar korkunç bir nişane şimdiye kadar hiç görülmemişti. Bu alamet, gitgide yükselerek gögün şimal kısmını tepeye doğru uzanan çizgilerle kapladı. Bütün yıldızlar ateş rengini aldılar. Bu nişane, bir hiddet ve felaket nişanesi idi. Bu olaydan klsa süre sonra 1099 / 1100 tarihinde mutat surette bir ay tutulmasl vuku buldu. Ay, önce birinci saatten dördüncü saate kadar koyu kan rengini aldı. Sonra karardl ise de tekrar kan renginde imiş gibi

\footnotetext{
${ }^{81}$ Ahmed bin Mahmud, Selçuk-Nâme, s.164; Azîmî’ye göre 485- 1092/1093 yılında Merih (Mars) ve Zuhal (Satrün) gezegenleri Seretan (Yengeç) burcunda bir araya geldiler. Azîmî, Azîmî Tarihi, s. 32.

82 Azîmî, Azîmî Tarihi, s. 35.

83 İbnü'l-Esîr yıldızın 20 gün göründüğ̈nü söyler. İbnü’l-Esîr, El Kâmil Fi’t-Tarih, C.X., s. 226; Azîmî, bu kuyruklu yıldızın 12 gece kaldıktan sonra kaybolduğunu söylemektedir. Azîmî Tarihi, s.36; Mateos ise yıldızın on beş gün göründüğünü söyler. Urfalı Mateos Vekayi-Nâmesi, s. 193.
} 
görünüyordu. Bu karartı o kadar koyu idi ki yeryüzü karanlık içinde kaldl. Âlimler, bunun Iranlılar tarafindan bu milletin kitaplarında aya dair bulunan yazılara göre, kan döküleceğine bir alamet olduğunu söylediler. Ayn yıl başka bir olay yaşandı ve gökyüzünde koyu kırmızı renkte ateşli alamet tekrar göründü. Bu alamet, şimal tarafindan şarka doğru gitmekte olup gecenin yedinci saatine kadar gözlere göründü ve alamet sonra karardl. Bunun, Hristiyanların kanının döküleceğine dair bir işaret olduğu söylendi." 84

Kaynaklardan yararlanılarak verilen örneklerden de anlaşıldığı gibi farklı coğrafyalarda yaşanmış olsa da neredeyse bütün tarihî kaynaklarda kendisine yer bulan ve meydana geldiği anda toplumlar üzerinde olumsuz etkilere sebebiyet veren sıra dışı gökyüzü olaylarının anlatılış tarzı ve yöntemi, müelliflerin dinî inançları ve taassupları ile doğrudan ilgilidir. İslami yazarlar konuya dair bilgi verirken genellikle yaşananları olduğu gibi yansıtmış hatta bazen olayları sayısal veriler ile anlatarak daha objektif bir bakış açısı tercih edip hadiselerden farklı anlamlar çıkarmamışlardır. Bizanslı tarihçiler de sıra dışı gökyüzü olaylarını süslü cümlelerden kaçınarak olabildiğince sade bir şekilde anlatmaya özen göstermişlerdir. Ancak Ermeni tarihçiler, doğal afetlere dair sabit bakış açılarını bu vakalarda da sürdürmüşler ve her sıra dışı gökyüzü olayından farklı anlamlar çıkarmak için adeta birbirleri ile yarışmışlardır. Gürcü tarihçiler de Ermeniler ile benzerlik gösterir şekilde yaşanan olayı destansı bir dille ve dinî taassupla ele almaya gayret göstermişlerdir.

\section{E) XI. Yüzyılda Yaşanan Önemli Atmosfer Olayları ve Sonuçları}

XI. yüzy1l boyunca Anadolu'da yaşayan halkları derinden etkileyen, büyüklükleri ve sonuçları ile tarihî kaynaklarda kendilerine yer bulan önemli atmosfer olayları yaşanmıştır. Bu olaylardan ilk bahseden Bizanslı tarihçi Skylitzes olmuştur. Onun ilk kayıtlarından 1010 / 1011 yılının kış aylarında çok şiddetli bir soğuğun olduğunu; bütün nehir ve göllerin hatta denizlerin bile donduğunu öğreniyoruz. ${ }^{85}$

Olağandışı atmosfer olayları ile alakalı olarak bilgi vermeye devam eden Skylitzes, 1029 yılı olayından sonra başlayan sağanak yağmurun Mart (Mart 1030) ayına kadar yağdığını ardından nehirlerin yükseldiğini ve boşlukların bütünüyle göle dönüştüğünü ardından ise bütün çiftlik hayvanlarının boğulduğunu ve ekinlerin yerlere yattığını söylemektedir. Yaşanan bu yağmur ve sel felaketinin ertesi yıllarda şiddetli kıtlığa sebep olduğunu aktarmaktadır. ${ }^{86}$

\footnotetext{
${ }^{84}$ Urfalı Mateos Vekayi-Nâmesi, s. 198, 200, 202

${ }^{85}$ Skylitzes, A Synopsis of Byzantine History, s. 330.

${ }^{86}$ Skylitzes, A Synopsis of Byzantine History, s. 356.
} 
Bizanslı tarihçiye ek olarak İslam kaynakları da atmosfer olayları hakkında bilgi vermektedir. İbnü'l-Esîr ve İbn Kesîr, H. 425 (1033 / 1034) yılında Nusaybin'de şiddetli bir toz fırtınasının estiğini ve bahçelerdeki pek çok ağacı kökünden kopardığını söylemekte ve bazı bahçelerde kireç ve tuğladan yapılmış köşklerin olduğunu, onların da firtına yüzünden kökünden söküldüğünü iddia etmişlerdir. ${ }^{87}$ Tarihçi Abû’l Farac, bu olayı kısaca şöyle aktarmaktadır: “Arapların 425 (1033) ve Yunanlıların 1355 (M.1034) yılının Aralık ayında (Muharrem / Sefer 425) Nisibis'de (Nusaybin) şiddetli bir karayel esti. Zeytin, dut ve erik ağaçlarını kökünden söktü. Taş ve kireçten yapılma binalar yıkıldı. Daha sonra şiddetli bir yă̆mur yă̆dı ve el, parmak ve bilek şeklinde dolular yağdı." 88

Bilgi vermeye devam eden Skylitzes, 1034 y1lında Easter gününün on birinci saatinde sadece ağaçları değil, şiddetiyle evleri ve kiliseleri de yıkan büyük bir dolu firtınasından bahsetmektedir. Fırtınanın şiddeti ekinleri ve asma bahçelerini yerlere yatırmış, hatta bu zamandaki bütün mahsullerde büyük yokluklara sebep olmuştur. ${ }^{89}$

Azîmî, yüzyılın ikinci yarısında iki farklı atmosfer olayı hakkında bilgi vermektedir. Eserde verilen malumatlara bakılırsa, 442 (1050 / 1051) yılında Antakya'daki Kusyân Kilisesi'ne yıldırım düşmüş; zincirleri kırılan çan, susmuştur. ${ }^{90} \mathrm{Bu}$ olaydan yaklaşık bir yıl sonra 1052 / 53' te İstanbul'da meydana gelen bir yangın şehrin hazinelerini yakmış; Temmuz ayında ise vakitsizce gelen ve üç gün süren yağmur, halkı zor durumda bırakmıştır. ${ }^{91}$ Skylitzes eserinde 1054 yılının yaz aylarında (Haziran - Eylül) yalnızca hayvanların değil insanların da ölümüne neden olan çok büyük bir dolu firtınasından bahsetmektedir. ${ }^{92}$

Ermeni tarihçiler Mateos ve Simbat'ın eserlerinde de atmosfer olayları ile ilgili kayıtlara rastlanmak mümkündür. Ancak bilgiler yüzyılın ikinci yarısından itibaren meydana gelen vakalarla başlamıştır. Yazarlar, yaşanan doğa olayları gibi atmosfer olaylarında da ilahi bir sebep - sonuç ilişkisi aramışlar ve bunları tanrısal işaretler olarak yorumlamışlardır. Onlara göre 1058 / 1059 yılının kış ayında Hristiyanlara ilahi hiddetini anlatan korkunç bir nişane belirdi. Bir leşten çıkan kokulardan dolayı Hristiyanların mahvolacakları, tehdit edici alametlerle daha önceden belirmişti. Günün birinde sabah erken vakitlerde herkesin evinden çıktığı sırada hava açık olduğu hâlde toprağın kırmızı karla örtülü olduğunu görülmüş ve bu kar memleketin her

\footnotetext{
87 İbnü'l-Esîr, El Kâmil Fi 't-Tarih, C. IX., s. 335,336; İbn Kesîr, El Bidaye Ve'n-Nihaye, C.XII., s. 120.

${ }^{88}$ Abû'l-Farac, Abû'l-Farac Tarihi, s. 291.

${ }^{89}$ Skylitzes, A Synopsis of Byzantine History, s. 371.

${ }^{90}$ Kusyân Kilisesi, 1055/56 yıllarında Partik Bedros tarafından tamir ettirildi. Azîmî, Azîmî Tarihi, s. 12,16.

${ }^{91}$ Azîmî, Azîmî Tarihi, s. 14.

92 Skylitzes, A Synopsis of Byzantine History, s. 445.
} 
tarafına yayılmıştır. Kar, pazartesi günü yağmaya başlamış ve altmış gün hiç durmadan yağmıştır. Kar, gece yağıyor; gündüz de toprağın üzerinden akıyordu. Kırmızı kar, bir gün yağdı. O yıl, bütün ehlî ve yabani hayvanlar telef oldu. Hayvanlarla kuşların insanların günahları yüzünden maruz kaldıkları bu telefat, feci bir manzara arz ediyordu. Bu yılda bütün memlekette şiddetli bir kıtlık oldu ve çok sayıda insan acıklı bir şekilde öldü. Çünkü karın çokluğu yüzünden yağmur yağmadı; mahsul yetişmedi ve birçok meyve ağacı kurudu. ${ }^{93}$

Bizanslı tarihçi Attaleiates, XI. yüzyılın son çeyreğinde İstanbul'da meydana gelen bir yıldırım düşme vakası hakkında bilgi vermektedir. Kayıtlara göre: "Üçüncü taşınmaz mallarda vergi değerini belirleme döneminin ekim ayında Konstantinos Forumu'nda (Çemberlitaş Meydanında ), üstünde "Anelios" adı verilen dev boyuttaki tunçtan bir eserin bulunduğu büyük bir sütuna yıldırım düştü.” Bu olayın, İmparator Botaneiates'in son dönemlerinde yaşandığ bilinmekle birlikte yıldırımın takriben 1080 yılının ekim ayı içerisinde düştüğü anlaşılmaktadır. ${ }^{94}$

Yüzyılın en son sıra dışı atmosfer olayına tarihçi Mateos'un eserinde rastlamaktayız. Yazar, her zaman yaptığı gibi meydana gelen bu olayı da geleceğe dönük bir kehanet olarak görmüş ve olayı şöyle kaleme almıştır: "548 (25 Şubat 1099 - 24 Şubat 1100) yılı içerisinde günün birinde şimşekler çakmaya başladı ve Vahga Kalesi’ne bir yıldırım düşı̈u. Yıldırım, kalede hizmetçilere ait odanın içine düşüp gümüş bir tepsiye çarptı ve bir parçasını koparıp uçurdu. Bütün âlimler, bu afetin Konstant'in son yılına alamet olduğunu söylediler. "95

\section{Sonuç}

XI. yüzyılda yaşanan depremler, doğal afetler ve birçok farklı sebebin sonucunda ortaya çıkan kıtlık, kuraklık ve salgın hastalıklar, yıkıcı etkisi ve neden olduğu ölümlü vakalardan dolayı kaynaklarda kendisinden en çok söz ettiren sıra dışı doğa olayları olarak karşımıza çıkmaktadır. Bu hadiseler meydana geldiği coğrafyanın siyasi yapısına olumsuz yönde tesir ettiği gibi bölgede sosyal, kültürel ve ekonomik yaşantının da sekteye uğramasına sebebiyet vermiştir. Felaketlerin neden olduğu yıkım ve tahribat sonrası yaşanan, açlık, fakirlik ve fiyatların aşırı yükselmesi hayat şartlarını büyük ölçüde zorlaştırmıştır. Ortaya çıkan bu

\footnotetext{
${ }^{93}$ Urfalı Mateos Vekayi-Nâmesi, s. 109,110; Başkumandan Simbat Vekayinamesi, s. 37.

${ }^{94}$ Anna Komnena, heykeli şöyle tasvir etmektedir; Konstantin alanının ortasında, porfir'den ( Mor Mermer) pekte dikkate değer bir sütün üzerinde yükselen ve doğuya bakan tunçtan bir heykel bulunuyordu; sağ elinde bir saltanat asas1, son elinde ise tunçtan dökülmüş bir küre tutuyordu. Anna Komnena, Alexiad, s. 372; Michaelis Attaliotae, Historia, s. 310; Attaleiates, Tarih, s. 305,306.

${ }^{55}$ Seyhan nehrinin doğusunda bulunan kaledir ve bu günkü adı Feke'dir. Urfalı Mateos Vekayi-Nâmesi, s.201. d.n.239.
} 
zorluklar ile mücadele etmek mecburiyetinde kalan bölge halkları ise göç etmeyi kendileri için bir çıkar yol olarak görmüşlerdir. Ancak dönem içerisinde sebebi ne olursa olsun yapılan kitlesel göç olayları büyük yerleşim yerleri ile verimli araziler hariç birçok bölgenin uzun yıllar 1ssızlaşmasına neden olmuştur.

Meydana geldiği coğrafyada yaşayan her topluluğu çöküşün eşiğine getiren ve önemli siyasi değişikliklere sebebiyet veren doğa olaylarına kayıtlarında yer veren yazarların başında Urfalı Mateos gelir. Yazar, yaşanan olayları ayrıntılı olarak kaleme alırken genel olarak Hristiyan yazarların sahip olduğu dinî taassuptan taviz vermemiş; hadiselerin sebeplerini yer yer kendilerinin dinden sapmaları olarak görmüş yer yer de Tanrı'nın onları cezalandırdığını düşünmüş ve hadisleri Tanrısal işaret veya uyarı olarak yorumlamıştır. Özellikle yüzyılın ikinci yarısından itibaren yaşanan Türk akınlarını, kıtlık ve salgın hastalıkların müsebbibi olarak gören yazar, kurtuluşun çaresi olarak da yine Tanrı'yı göstermiştir.

Başka bir Hristiyan yazar olan Simbat, olaylara yaklaşım şekliyle ve anlatım tarzıyla Urfalı Mateos'a benzerlik gösterirken, eserlerinden anlaşıldığı kadarı ile Skylitzes, Attaleiates ve Zonaras gibi Bizanslı tarihçiler de İmparatorluk merkezi olan İstanbul'da bulunmalarının vermiş olduğu rahatlıkla hadiselere daha soğukkanlı bakmışlar ve dinî kaygılardan uzak daha objektif bir şekilde vakaları kaleme almaya çalışmışlardır.

$\mathrm{Bu}$ dönemin önemli tarih yazıcılarından birisi olan Süryani Mikhail ise olayları kaleme alış tarzı olarak Ermeni yazarlar ile benzerlik gösterirken yaşanan doğa olaylarının sebeplerine dair yorumlar yapmış; ancak o da Mateos gibi mezhep meselelerini ön planda tutmaya çalışmıştır. Müslüman yazarlar arasında en önemlisi olarak görülen İbnü’l-Esîr vakaları Hristiyan yazarların aksine sıradan olaylar olarak görmüş, sebep arama çabalarına girişmeden sade bir dille olayları kaleme almış; İbn Kesîr ise yazım tarzı ve olaylara bakış açısı olarak İbnü'l-Esîr ile benzerlik göstermiştir. Yukarıda bahsedilen yazarların vermiş olduğu bilgilere ek olarak az da olsa farklı olaylara eserlerinde yer veren Azîmî ve Abû'l-Farac gibi tarihçiler de dönem içerisinde bölgenin yaşamış olduğu sıkıntılara ve sorunlara ışık tutarak vakaların farklı yönlerinin ortaya çıkmasına yardımcı olmuşlardır. Anadolu'nun XI. yüzyılına dair oldukça zengin bilgilere sahip olan bu kaynakların, her ne kadar olaylara bakış açıları farklılık gösterse de hemfikir oldukları nokta aslında şudur: Coğrafya üzerinde yaşayan halkların farklı din, dil ve ırklara tabi olması maruz kaldıkları yıkıcı felaketler karşında önemini yitirmiş ve yaşanan acılar bütün inançlara mensup toplumları aynı şekilde etkilemiştir. 


\section{Kaynakça}

Ahmed bin Mahmud, (1997). Selçuk-Nâme, Haz. Erdoğan Merçil, İstanbul.

Andreasyan, Hrand D. (1949). “Türk Tarihine Aid Ermeni Kaynakları”, İstanbul Ünv. Edebiyat Fakültesi Tarih Dergisi, C.1, Say1 1., s. 95-118.

Andreasyan, Hrand D. (1950). “Türk Tarihine Aid Ermeni Kaynakları”, İstanbul Ünv. Edebiyat Fakültesi Tarih Dergisi, C.1, Sayı 2., s. 401-438.

Anna Komnena, Alexiad, (1996) Anadolu'da ve Balkan Yarımadası'nda İmparator Alexios Komnenos Dönemi’nin Tarihi, Malazgirt'in Sonras1, çev.: Bilge Umar, İstanbul.

Anonim Haçlı Tarihi, (2013). çev.: Ergin Ayan, İstanbul: Selenge Yay.

Arik, Feda Ş. (1991). "Selçuklular Zamanında Anadolu'da Veba Salgını”, Ankara Üniversitesi Dil ve Tarih-Coğrafya Fakültesi Tarih Bölümü Tarih Araştırmaları Dergisi, Cilt: 15, Say1: 26, s.27-57.

Aristo, (1931). Meteorologica,-The Works of Aristotle-, Vol III., By, E.W. Webster.-Trans.: W.D.Ross, M.A., Hom, LL.D., Oxford.

Arslantaş, N. (2003). İslam Dünyasında Depremler ve Algılanma Biçimleri, İstanbul.

Attaleiates, M. (2008). Tarih, çev.: Bilge Umar, İstanbul: Arkeoloji ve Sanat Yay.

Attaliotae, M. (1853). Historia, (Invent, Descript, Correct Immanel Bekkerus), Bonnae.

Azîmî, (2006). Azîmî Tarihi, Selçuklular Dönemiyle ilgili Bölümler (H.430-538=1038/391143/44), Ali Sevim, Ankara: TTT. Yay.

Başkumandan Simbat Vekayinamesi (951-1334), Türkçeye çev.: Hrant D. Andreasyan, TTK Basılmamış Nüsha, İstanbul 1946.

Brosset, Marie F. (2003). Gürcistan Tarihi, (Eski Çağlardan 1212 yılına Kadar), çev.: Hrand D. Andreasyan, Not. ve Yay., Erdoğan Merçil, Ankara: TTK. Yay.

Delilbaşı, M. (1999). “Türk Tarihinin Bizans Kaynakları”, Cogito- Bizans-, Sayı 17, s. 339-351, İstanbul: Yap1 Kredi Yay.

Demirkent, I. (2000). "Bizans Kaynaklarına Göre IV.-XI. Yüzyıllarda İstanbul'da ve Çevresinde Depremler", Tarih Boyunca Anadolu'da Doğal Afetler ve Deprem Semineri, İstanbul, s. 51-65. 
Downey, G. (1955). "Eartquakes at Constantinople an Vicinity, A.D. 342-1454", Speculum, VOl. 30, No. 4, pp. 596-600.

Fasîh Ahmed b. Celaleddin Muhammed Hâfî, (1961). Mücmel-i Fasîhî, C. II., Neşr.: Muhammed Ferrruh, Meşhed 1340.

Gautier, P. (1966). "Monodie inédite de Michel Psellos sur le basileus Andrinic Doucas", Revue des études byzantnes, tome 24,. ss. 153-170.

Glycas, M. (1836). Annales, Immanuel Bekkerus, Bonnae.

Gregory Abû'l-Farac (Bar Habraeus), (1999). Abû'l-Farac Tarihi, Süryaniceden İng. çev.: Ernast A. Wallis Budge, Trk. çev.: Ömer Rıza Doğrul, C.I., Ankara: TTK. Yay..

Günaltay, M. (1991). Şemseddin, İslam Tarihinin Kaynaklart-Tarih ve Müverrihler-, İstanbul: Endülüs Yay.

Ioannes Z. (2008). Tarihlerin Özeti, çev.: Bilge Umar, İstanbul: Arkeoloji Sanat Yay.

Ioannis Z. (1897). Epitomae Historiarum, Libri XIII-XVIII, Edit., Theodorus Büttner-Wobst, Bonnae Impensisi Ed. Weberi.

İbn Kesîr, (1985). El Bidaye Ve'n Nihaye, çev. Mehmet Keskin, İstanbul: Çağrı Yayınları İbnü'l-Esîr, (1985). El Kâmil Fi’t-Tarih, çev.: Ahmet Ağırakça, Abdülkerim Özaydın, Yunus Apaydın, Zülfikar Tüccar, Beşir Eryarsoy, İstanbul: Bahar Yayınları

Kesik, M. (2000). “Cenâbî’ye Göre Türkiye Selçukluları”, İstanbul Üniversitesi Edebiyat Fakültesi Tarih Dergisi, sy. 36, s.213-259.

Mikhail Psellos Khronographia'sı, (1992). çev.: Işın Demirkent, Ankara: TTK. Yay.

Müverrih V. (1937). Türk Fütuhatı Tarihî (889-1269), çev.: Hrant D. Andreasyan, İstanbul.

Nicolle, D. (2010). Birinci Haçlı Seferi 1096-99, çev.: Ece Sakar, İstanbul: İş Bak. Kültür Yay.

Runcıman, S. (2008). Haçl Seferleri Tarihi, Birinci Haçlı Seferi ve Kudüs Krallı̆̆ının Kuruluşu, C. I. çev.: Fikret Işıltan, Ankara.

Sıbt İbnu'l-Cevzî, (2011). Mir'âtü'z-Zamân Fî Târîhi'l-Âyân'da Selçuklular, Seçme Türcüme ve Değerlendirme Ali Sevim, Ankara: TTK. Yay. 
Skylitzes, J. (2011). A Synopsis of Byzantine History, 811-1057, Introduction, Text And Notes Translated By John Wortley, Cambridge University Press

Süryani Patrik Mihail Vakainamesi (1944), İkinci Kısım (1042-1195), Türkçeye Çeviren Hrant D. Andreasyan, İstanbul: TTK. Basılmamış Nüsha

Urfalı Mateos Vekayi-Nâmesi (952-1336) ve Papaz Girgor'un Zeyli (1136-162), çev.: Hrand D. Andreasyan, Not. Edouard Dulaurer, M. Halil Yınanç, Ankara: TTK. Yay., 2000.

Vercleyen, F. (1997). "Bizans Döneminde İstanbul'da Depremler: Halk Üzerinde Etki”, Ankara Üniversitesi Dil ve Tarih-Coğrafya Fakültesi Tarih Bölümü Tarih Araştırmaları Dergisi, Fransızcadan çev.: Feda Şamil Arık, Cilt. 19, Sayı 30, s. 299-317. 